UNIVERSIDADE DE SÃO PAULO

FACULDADE DE FILOSOFIA, LETRAS E CIÊNCIAS HUMANAS

DEPARTAMENTO DE CIÊNCIA POLÍTICA

PROGRAMA DE PÓS-GRADUAÇÃO EM CIÊNCIA POLÍTICA

MARCELA SILVEIRA TULLII

Para Além Da Judicialização: Política Pública Da Justiça No Campo

Da Saúde

São Paulo 
UNIVERSIDADE DE SÃO PAULO

FACULDADE DE FILOSOFIA, LETRAS E CIÊNCIAS HUMANAS

DEPARTAMENTO DE CIÊNCIA POLÍTICA

PROGRAMA DE PÓS-GRADUAÇÃO EM CIÊNCIA POLÍTICA

\section{Para Além Da Judicialização: Política Pública Da Justiça No Campo} Da Saúde

Marcela Silveira Tullii

Dissertação de Mestrado apresentada ao Programa de Pós-Graduação em Ciência Política da Faculdade de Filosofia, Letras e Ciências Humanas da Universidade de São Paulo, como parte dos requisitos para obtenção do título de Mestre em Ciência Política.

Orientador: Prof. Dr. Rogério Bastos Arantes

São Paulo 
Autorizo a reprodução e divulgação total ou parcial deste trabalho, por qualquer meio convencional ou eletrônico, para fins de estudo e pesquisa, desde que citada a fonte.

Catalogação na Publicação

Serviço de Biblioteca e Documentação

Faculdade de Filosofia, Letras e Ciências Humanas da Universidade de São Paulo

Tullii, Marcela SIlveira

T918p Para Além Da Judicialização: Política Pública Da Justiça No Campo Da Saúde / Marcela SIlveira Tullii, orientador Rogério Bastos Arantes. - São Paulo, 2017. $86 \mathrm{f}$.

Dissertaçăo (Mestrado) - Faculdade de Filosofia, Letras e Ciências Humanas da Universidade de São Paulo. Departamento de Ciência Politica. Área de concentração: Ciência Politica.

1. Judicialização da Política. 2. Direito à Saúde. 3. Conselho Nacional de Justiça. I. Arantes, Rogério Bastos, orient. II. Título. 
TULlII, M. Para Além da Judicialização: Políticas Públicas da Justiça no Campo da

Saúde. Dissertação apresentada à Faculdade de Filosofia, Letras e Ciências Humanas da Universidade de São Paulo para obtenção do título de Mestre em Ciência Política

Aprovado em:

Banca Examinadora

Prof. Dr. Instituição:

Julgamento: Assinatura:

Prof. Dr. Instituição:

Julgamento: Assinatura:

Prof. Dr. Instituição:

Julgamento: Assinatura: 
À minha irmã, companheira e mais querida amiga, por seu incansável e ininterrupto apoio, em todas as esferas da minha vida. Que sorte minha tê-la sempre ao meu lado.

Aos meus pais, por seus muitos acertos e poucos erros que me tornaram quem eu sou.

À minha Oma, por sua admirável sensibilidade e postura diante do mundo; e pela acolhida sempre afetuosa.

E, por fim, à minha tia Pinha. Por ser uma insipiração pela via do exemplo; e por seu apoio silencioso, que me possibilitou tantas coisas, mas que nunca requereu reconhecimentos. Que minhas pequenas conquistas sejam um agradecimento à sua altura. 


\section{Agradecimentos}

Agradeço à CAPES (Coordenação de Aperfeiçoamento de Pessoal de Nível Superior) pela concessão da bolsa durante o período de realização do Mestrado.

Agradeço ao Programa de Pós Graduação em Ciência Política da Universidade de São Paulo, pelo apoio na conclusão do Mestrado, que se manifestou em diversas formas: na disponibilização de espaços de estudo, de impressões, de esforços coletivos para manter a alta qualidade da produção no departamento, pelos seminários organizados, pela esforço de trazer professores visitantes, e por tantas outras iniciativas. E ao Vasne e a Marcia, por sempre estarem dispostos a nos ajudarem com as burocracias da pós-graduação com sorriso no rosto.

Agradeço aos professores Eduardo Marques e Janaína Penalva por comporem minha banca de qualificação, lerem com cuidado o material que apresentei e me ajudarem a pensá-lo criticamente.

Agradeço ao meu orientador, professor Rogério Arantes, pela orientação, que foi fundamental não só para elevar a qualidade do trabalho, mas para que sua conclusão fosse possível. Pude contar com rápidas respostas aos meus emails, revisões de texto meticulosas, uma sensibilidade na compreensão de angústias e, apesar das formalidades, palavras de apoio e incentivo que foram fundamentais na reta final.

Agradeço aos participantes do grupo de estudos do Judiciário, pela interlocução contínua e por ajudar a tornar a experiência acadêmica menos solitária: Cassio, Guilherme, Jeferson, Rodrigo, Thiago Moreira, Thiago Fonseca e Rebeca.

Agradeço também a todos os entrevistados, que gentilmente me cederam um tempo em suas agendas para que essa pesquisa fosse possível.

Agradeço ao acaso que é a vida por ter trazido duas grandes amigas de longa data de volta ao meu convívio rotineiro, e que foram essenciais para manter meu equilíbrio na fase final de redação dessa dissertação: Maira e Iara.

Agradeço aos amigos que perdoaram as minhas ausências, em particular: Aline, Ana, Clau, Mari, Marina, Teh e Woody. Ao João e ao Bruno, por mandarem uns salves de tempos em tempos para se certificarem que tudo estava bem.

Ao Rodrigo, cabe ainda um agradecimento individual, por ter me ajudado a entrar - e também a sair - dessa jornada que foi o mestrado; pela paciência que nunca faltou, por ter me mostrado com gestos o que não conseguia dizer com palavras, pelos favores feitos e nunca cobrados, pela escuta ativa e postura acolhedora, por redefinir minha concepção de companheirismo, com o qual pude contar mesmo quando a natureza da nossa relação mudou. Obrigada por ter sido, por tantos anos, meu arrimo. 


\section{RESUMO}

\section{TULlII, M. Para Além da Judicialização: Políticas Públicas da Justiça no Campo}

da Saúde. Dissertação (Mestrado) - Faculdade de Filosofia, Letras e Ciências Humanas, Universidade de São Paulo, (2017).

O fenômeno da "judicialização da política" tem suscitado o interesse de inúmeros pesquisadores, especialmente a partir dos efeitos produzidos pela nova configuração constitucional de 1988. No Brasil, os estudos empíricos acerca da judicialização da política têm se concentrado em dois grandes grupos: 1) na análise do Supremo Tribunal Federal e no controle concentrado de constitucionalidade e 2) na análise da judicialização que ocorre por meio da Justiça Comum em processos individuais ou coletivos que envolvem políticas públicas. Parte expressiva da bibliografia existente sobre o tema da judicialização de políticas públicas se concentra na questão do acesso à saúde, por ser essa uma área que conheceu o maior volume de ações na Justiça Comum nos últimos anos.

Limitados quase sempre à análise de jurisprudência, esses estudos raramente nos dão a conhecer o comportamento do Judiciário enquanto instituição que é acionada por atores individuais, coletivos e estatais no campo da saúde. Esse trabalho pretende analisar uma das respostas institucionais do Judiciário brasileiro às crescentes demandas por assistência à saúde que chegam pela via judicial: o Fórum Nacional do Poder Judiciário para Monitoramento e Resolução das Demandas de Assistência à Saúde Fórum da Saúde, criado por iniciativa do Conselho Nacional de Justiça (CNJ) em 2010. O objetivo principal dessa dissertação é mostrar como o processo de judicialização da saúde se desdobrou nessa iniciativa de institucionalização de uma política pública da justiça, na forma assumida pelo Fórum da Saúde.

Entendemos aqui que a experiência de criação e implementação do Fórum da Saúde configura uma "política pública da Justiça". Trata-se, assim, de uma política liderada por um órgão do Poder Judiciário que, valendo-se de seu caráter administrativo e não jurisdicional, chama para si a responsabilidade de organizar os termos da política pública frequentemente judicializada, enredando por essa via atores jurídicos e não jurídicos, governamentais e não governamentais em sua concepção e implementação.

Palavras-Chave: Judicialização da Política, Direito à Saúde, Conselho Nacional de Justiça 


\section{ABSTRACT}

\section{TULLII, M. Beyond Judicialization: Public Policy fom Justice System in the}

Healthcare Area. Dissertação (Mestrado) - Faculdade de Filosofia, Letras e Ciências Humanas, Universidade de São Paulo, (2017).

The phenomenon of "judicialization of politics" has aroused the interest of many researchers, especially after the effects produced by the 1988 constitutional configuration. In Brazil, empirical studies about the judicialization of politics have mainly focused on two categories: 1) in the analysis of the Federal Supreme Court and in the abstract constitutional control and 2) in the analysis of the judicialization that occurs through the Common Justice in individual or collective processes that involve public policies. A significant part of the existing bibliography on the subject of the judicialization of public policies focuses on the issue of access to healthcare, given it is the area that has seen the greatest volume of actions in Common Justice in recent years.

Generally limited to the analysis of jurisprudence, these studies rarely explore the behavior of the Judiciary as an institution that is driven by individual, collective and state actors in the field of healthcare. This study intends to analyze one of the institutional responses of the Brazilian Judiciary to the growing lawsuit actions that demand healthcare assistance: the National Forum of the Judiciary for Monitoring and Resolution of Health Care Claims - Health Forum, created at the initiative of the National Justice Council (CNJ) in 2010. The main objective of this dissertation is to show how the process of health judicialization has unfolded in this initiative of institutionalizing a public policy of justice, in the form assumed by the Health Forum.

We argue that the experience of creating and implementing the Health Forum configures a "public policies of justice". It is thus a policy led by an agency of the Judiciary which, by virtue of its administrative and non-jurisdictional nature, calls for the responsibility of organizing the terms of the often-judicialized public policy, thereby entangling legal and non-legal, governmental and non-governmental actor, in their design and implementation.

Key-Words: Judicialization of Politics, Right to Health, Nacional Justice Council 


\section{LISTA DE FIGURAS}

Figura 1 - Composição do Conselho Nacional da Justiça nas diferentes propostas da Câmara dos Deputados (não inclui Senado nem a definição final) ................................20

Figura 2 - A construção da autoridade prática, segundo Abers e Keck (2013)..............50

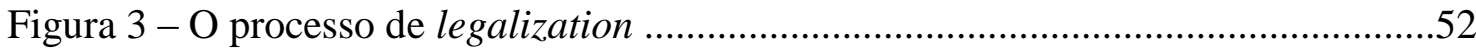




\section{LISTA DE SIGLAS E ABREVIATURAS}

ADI - Ação Direita de Inconstitucionalidade

AMB - Associação dos Magistrados Brasileiros

ANS - Agência Nacional de Saúde Suplementar

ANVISA - Agência Nacional de Vigilância Sanitária

AP - Audiência Pública

CF - Constituição Federal

CFM - Conselho Federal de Medicina

CIB - Comissão Intergestores Bipartite

CIT - Comissão Intergestores Tripartite

CNJ - Conselho Nacional de Justiça

CONASEMS - Conselho Nacional de Secretarias Municipais de Saúde

CONASS - Conselho Nacional de Secretários de Saúde

CONITEC - Comissão Nacional de Incorporação de Tecnologias no SUS

MS - Ministério da Saúde

NAT - Núcleo de Apoio Técnico

PCDT - Protocolo Clínico e Diretrizes Terapêuticas

PEC - Proposta de Emenda Constitucional

PROADI - Programa de Apoio ao Desenvolvimento Institucional do SUS

PT - Partido dos Trabalhadores

RE - Recursos Extraordinário

STA - Suspensão de Tutela Antecipada

STF - Supremo Tribunal Federal

STJ - Supremo Tribunal de Justiça

STM - Superior Tribunal Militar

SUS - Sistema Único de Saúde

TJ - Tribunal de Justiça 
TSE - Tribunal Superior Eleitoral

TST - Tribunal Superior do Trabalho 


\section{Sumário}

INTRODUÇÃo

1. PODER JUdICIÁRIO, DIREITO À SAÚdE, E A POSSIBILIDADE DE JUDICIALIZAÇÃO DE DIREITOS NO BRASIL PÓS-88.

1.1. Estrutura e organização do Poder Judiciário no Brasil: Constituição de 1988 e pós$88 \quad 14$

1.2. O direito à saúde no Brasil: Constituição de 1988 e pós-88 .22

1.2.1. Estabelecendo o Direito à Saúde: A constituição de 1988. 22

1.2.2. Dando concretude ao direito à Saúde: as normas infra-constitucionais 24

1.3. Conclusão: A possibilidade de judicialização de direitos no Brasil: Constituição de 1988 e pós- 88

2. JUDICIALIZAÇÃO DO DIREITO À SAÚDE NA LITERATURA BRASILEIRA .. 29

2.1. Houve uma judicialização do direito à saúde no Brasil? O ciclo da judicialização 29

2.2. Organizando o debate: caracterizando a judicialização do direito à saúde no Brasil 32

2.3. Conclusão

3. AS RESPOSTAS INSTITUCIONAIS DO JUDICIÁRIO AO PROBLEMA DA

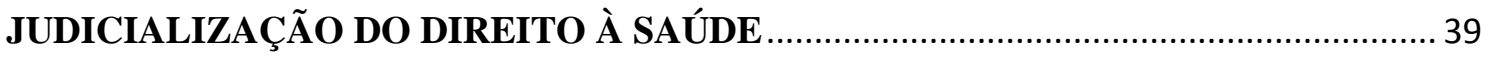

3.1. Respostas do Supremo Tribunal Federal ……................................................... 40

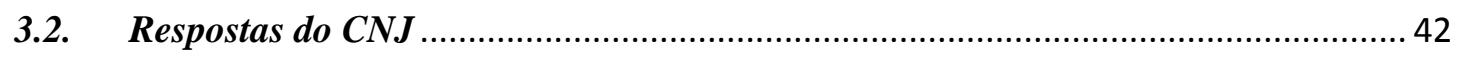

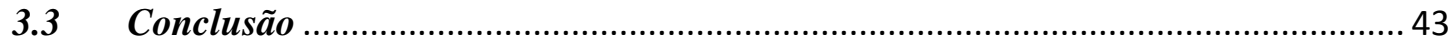

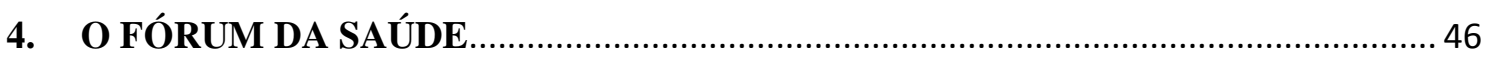

4.1. Autoridade Prática: Uma teoria para explicar como instituições se tornam

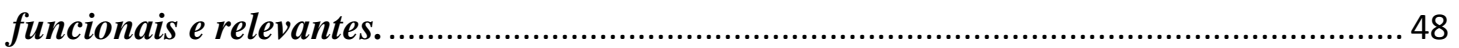

4.2. O Fórum da Saúde e a Construção de Autoridade Prática ...................................... 54

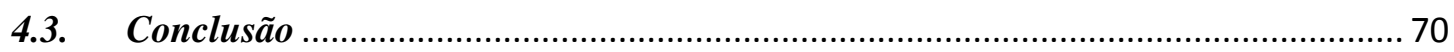

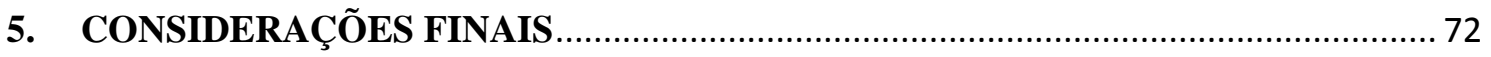

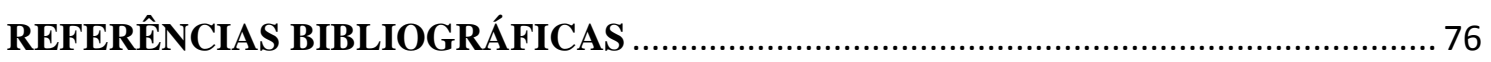

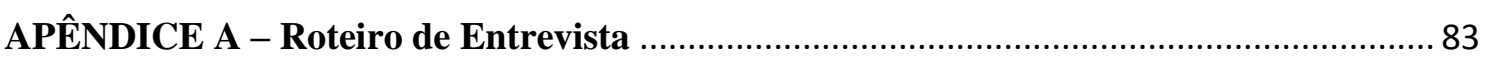

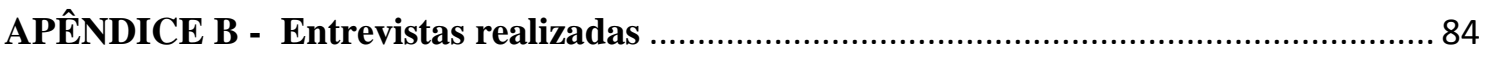




\section{INTRODUÇÃO}

O fenômeno da "judicialização da política" tem suscitado o interesse de inúmeros pesquisadores, especialmente a partir dos efeitos produzidos pela nova configuração constitucional de 1988. No Brasil, os estudos empíricos acerca da judicialização da política têm se concentrado em dois grandes grupos: 1) na análise do Supremo Tribunal Federal e no controle concentrado de constitucionalidade e 2) na análise da judicialização que ocorre por meio da Justiça Comum em processos individuais ou coletivos que envolvem políticas públicas.

Parte expressiva da bibliografia existente sobre o tema da judicialização de políticas públicas se concentra na questão do acesso à saúde, por ser essa uma área que conheceu o maior volume de ações na Justiça Comum nos últimos anos. As pesquisas tentam, em geral, averiguar a extensão do impacto das decisões judiciais nas políticas de saúde e no caráter do direito à saúde.

Limitados quase sempre à análise de jurisprudência, esses estudos raramente nos dão a conhecer o comportamento do Judiciário enquanto instituição que é acionada por atores individuais, coletivos e estatais no campo da saúde. Embora vários trabalhos tenham enfrentado a questão central - a controvérsia sobre a intervenção judicial numa área que procura se organizar como política pública - a literatura não se dedicou, até agora, a investigar formas e ações desenvolvidas pelo próprio Poder Judiciário, que extrapolam os processos judiciais e visam influenciar diretamente o desenho e o alcance de políticas públicas em áreas específicas, com atenção especial para o caso da saúde.

Esse trabalho pretende analisar uma das respostas institucionais do Judiciário brasileiro às crescentes demandas por assistência à saúde que chegam pela via judicial: o Fórum Nacional do Poder Judiciário para Monitoramento e Resolução das Demandas de Assistência à Saúde - Fórum da Saúde, criado por iniciativa do Conselho Nacional de Justiça (CNJ) em 2010. Entendemos aqui que a experiência de criação e implementação do Fórum da Saúde configura o que Arantes (2015) denominou, observando os diversos programas conduzidos pelo CNJ, de "políticas públicas da Justiça”. Trata-se, assim, de uma política liderada por um órgão do Poder Judiciário que, valendo-se de seu caráter administrativo e não jurisdicional, chama para si a responsabilidade de organizar os termos da política pública frequentemente judicializada, enredando por essa via atores jurídicos e não jurídicos, governamentais e não governamentais em sua concepção e implementação. 
O objetivo principal dessa dissertação é mostrar como o processo de judicialização da saúde se desdobrou nessa iniciativa de institucionalização de uma política pública da justiça, na forma assumida pelo Fórum da Saúde. Nesse sentido, cabe destacar que essa dissertação não será um estudo de avaliação de impacto dessa política pública nem da atuação concreta do Fórum, mas sim de análise de sua criação e de seu funcionamento inicial. Isso significa dizer que, mais do que olhar para os objetivos declarados da política e avaliar se eles foram ou não alcançados, o que se pretende é capturar o que motivou sua instituição nesse formato, a dinâmica interna a essa arena entre os atores e os momentos-chave que estruturaram a discussão e agenda por longos períodos, e o que se produziu em cada um desses ciclos.

Trabalharemos com duas hipóteses exploratórias para analisar o Fórum, provisoriamente entendidas como não excludentes. A primeira hipótese é que a instalação do Fórum teve por objetivo uniformizar verticalmente o entendimento das questões relacionadas a demandas em saúde, isto é, perfilar as instâncias inferiores do Poder Judiciário em torno dos termos e entendimentos comuns acerca dos conflitos envolvendo demandas por saúde, fixados a partir dos órgãos de cúpula do Judiciário, o Supremo Tribunal Federal e o Conselho Nacional de Justiça. A segunda hipótese é que a instalação do Fórum visou também a possibilidade de o Judiciário liderar uma uniformização horizontal destes termos e entendimentos na relação entre os poderes, isto é, a busca de coordenação entre a Justiça e os diversos órgãos do poder Executivo e demais atores institucionais envolvidos em questões de saúde. Embora nosso desenho de pesquisa não tenha se prestado exatamente a um teste final dessas hipóteses, elas foram guias importantes para o estudo do objeto, as análises histórica e documental, a realização das entrevistas, a discussão dos principais achados e a conclusão final do trabalho.

Essa dissertação se dividirá, além dessa breve introdução, em cinco capítulos. O primeiro capítulo, introdutório, apresentará suscintamente como o poder Judiciário se organiza no atual sistema constitucional brasileiro, como o direito à saúde aparece na constituição e como foi organizado por legislações posteriores, e os fatores institucionais e constitucionais que abriram a possibilidade de judicialização do direito à saúde no Brasil pós-88.

O segundo capítulo mostrará que a possibilidade de judicialização do direito à saúde se realizou, levando a uma intensa judicialização desse direito social, e apresentará como a literatura tem interpretado o fenômeno, organizando o debate a 
partir do que foi produzido em diferentes campos do conhecimento: Direito, Saúde Pública e Ciência Política.

No terceiro capítulo, apresentaremos o que chamamos de respostas institucionais do Poder Juciário à judicialização do direito à saúde, ou seja, iniciativas desse poder para lidar com a questão para além dos processos judiciais.

No quarto capítulo, apresentaremos o Fórum da Saúde, contextualizando o momento de sua criação e seus objetivos institucionais. Por meio da análise das normativas e iniciativas produzidas por essa instância, além da análise das informações coletadas por meio de entrevistas com atores que tem e tiveram participação importante nessa experiência, procuraremos argumentar como o Fórum, através de suas iniciativas e engajamento de novos atores, ganhou "autoridade prática", definida como o desenvolvimento de capacidades para resolver problemas e de ter o reconhecimento por outros atores-chave que permite a um ator (individual ou coletivo) influenciar comportamentos e tomar decisões que serão de fato seguidas por outros . (Abers e Keck, 2013)

Uma seção final trará as conclusões a respeito dos achados principais da pesquisa e, retomando as hipóteses mencionadas acima, fará uma discussão acerca de como uma iniciativa como o Fórum se encaixa no se convencionou chamar de judicialização da política, representando todavia um giro a mais no ciclo deste fenômeno, se considerada a forma como ele veio sendo analisado até o momento pela literatura especializada. 


\section{PODER JUDICIÁRIO, DIREITO À SAÚDE, E A POSSIBILIDADE DE JUDICIALIZAÇÃO DE DIREITOS NO BRASIL PÓS-88}

\subsection{Estrutura e organização do Poder Judiciário no Brasil: Constituição de 1988 e pós-88}

O Poder Judiciário no atual sistema constitucional brasileiro ${ }^{1}$ é composto por órgãos que atuam na típica função de prestação da justiça - a função jurisdicional, ou seja, a aplicação do direito para solucionar conflitos - e por um órgão sem função jurisdicional, de natureza administrativa e disciplinar, incluído no texto constitucional em 2004, por meio da Emenda Constitucional 45/2004: o Conselho Nacional de Justiça $(\mathrm{CNJ})$.

Os órgãos do Poder Judiciário de função jurisdicional são os juízes e os tribunais. Esses órgãos são organizados de acordo com a competência das matérias que podem julgar e o escopo geográfico de sua jurisdição, que pode ser federal ou estadual. União e estados são os responsáveis por sustentar os diferentes ramos da justiça. Assim, constituem justiças da União a Eleitoral (responsável pela organização e condução das eleições, em todas as suas fases), a Trabalhista (responsável pelo julgamento de conflitos envolvendo relações de trabalho) e a Federal stricto sensu (responsável pelo julgamento de conflitos nas quais a União é parte interessada, como ré ou proponente da ação). Por dedução, as causas que não são eleitorais, trabalhistas ou que não envolvam diretamente a União são examinadas e julgadas pela justiça comum dos estados, que concentram assim grande volume de processos civis e criminais dos mais variados tipos. A constituição ainda prevê a justiça militar para o julgamento de crimes cometidos por militares das três Forças Armadas, mas também das Polícias Militares e Corpos de Bombeiros. Por abarcarem essas diferentes corporações, a justiça militar contempla tanto órgãos federais quanto estaduais em sua organização.

A estrutura do Poder Judiciário, no que tange aos órgãos com função jurisdicional, também se caracteriza por uma hierarquia formada por instâncias. A primeira instância é a que primeiro recebe e julga uma ação apresentada ao Poder Judiciário. As demais instâncias, recursais, são responsáveis por reexaminar matérias já

\footnotetext{
${ }^{1}$ O Poder Judiciário ocupa o Título IV, Capítulo III, da Constituição Federal de 1988.
} 
decididas em primeira instância, seguindo o princípio do duplo grau de jurisdição, que no Brasil pode se desdobrar em até quatro.

A base desses órgãos, sejam de jurisdição estadual ou federal, compõe-se dos juízos de $1^{\circ}$ grau (juízes federais ou estaduais) e dos tribunais (5 Tribunais Regionais Federais, organizados por regiões, para a justiça federal especializada, 27 Tribunais Regionais Eleitorais para a justiça eleitoral especializada, 24 Tribunais Regionais do Trabalho, organizados por regiões $^{2}$, para a justiça trabalhista especializada e, finalmente, os 27 Tribunais de Justiça dos Estados e do Distrito Federal). Acima destes, e sediados em Brasília, encontram-se os tribunais superiores, quais sejam, o Tribunal Superior Eleitoral (TSE), o Tribunal Superior do Trabalho (TST) e o Superior Tribunal Militar (STM) como órgãos de cúpula das respectivas justiças federais especializadas, bem como o Superior Tribunal de Justiça (STJ), “corte responsável por uniformizar a interpretação da lei federal em todo o Brasil (...) sendo de sua responsabilidade a solução definitiva dos casos civis e criminais que não envolvam matéria constitucional nem a justiça especializada"3, e finalmente o Supremo Tribunal Federal (STF), órgão de cúpula de todo o Judiciário brasileiro, responsável por ações originárias especiais - tais como as envolvendo autoridades com foro privilegiado - mas principalmente pelo controle de constitucionalidade, seja na forma direta e abstrata (por meio de ações de inconstitucionalidade e/ou de descumprimento de preceito fundamental), seja na forma incidental e concreta, por meio dos recursos extraordinários. Desde 1988, o volume de recursos e ações diretas que desaguaram no STF foi imenso, chegando a ultrapassar a cifra de 100 mil processos por ano (Arantes 2015, 47). A facilidade de acesso ao tribunal, seja pela via recursal ou pela via direta, associada ao fato de que a Constituição de 1988 ser extensa e bastante detalhada, encerrando inclusive um grande número de políticas públicas (Couto e Arantes, 2006), explicam essa avalanche de processos sobre o Supremo Tribunal Federal.

A Constituição de 1988 também atribuiu ao Poder Judiciário importante autonomia orçamentária, financeira e administrativa. Em perspectiva comparada, o Judiciário brasileiro é um dos mais aquinhoados do mundo, em termos absolutos de recursos e relativos em relação ao PIB (Da Ros, 2015). Como poder autônomo

\footnotetext{
${ }^{2}$ Não estão presentes, portanto, individualmente, em todas as unidades federativas porque o Distrito Federal e o estado do Tocantins estão sob a jurisdição do mesmo TRT da $10^{\mathrm{a}}$ Região, Pará e Amapá estão sob a mesma jurisdição do TRT da $8^{\text {a }}$ Região, Roraima e Amazonas sob o TRT da $11^{\text {a }}$ Região, e Acre e Rondônia sob o TRT da $14^{\mathrm{a}}$ Região.

${ }^{3}$ Definição constante no site do Tribunal: http://www.stj.jus.br.
} 
responsável pela prestação da justiça, goza de independência funcional, forjada à base de garantias como a vitaliciedade, a inamovibilidade e a irredutibilidade de vencimentos, que protegem o magistrado a fim de que possa julgar com determinação e imparcialidade. Ou seja, tais garantias conformam a independência judicial decisional, segundo a qual o magistrado pode e deve decidir um caso a partir de sua livre interpretação dos fatos, mas com base nas leis e na Constituição, ao mesmo tempo em que desse vê protegido de qualquer tipo de sanção por qualquer decisão que venha a tomar com base nessa independência judicial decisional, seja por parte de outro órgão do Judiciário, como tribunais superiores, seja de um outro poder constitucionalmente constituído, como o Executivo ou Legislativo, seja da sociedade (FEREJOHN, 1999, p. 353). Evidentemente, para estar em conformidade com a independência judicial decisional, o magistrado deve retomar as principais informações do caso na sentença e justificá-la por meio das leis e da Constituição, a partir de sua interpretação particular dos fatos.

Apesar de cogitado em um ante-projeto de constituição (Projeto A elaborado pela Comissão de Sistematização) pela Assembleia Constituinte de 1987-88, um órgão de controle externo do Poder Judiciário na forma de um Conselho Nacional de Justiça não chegou a ser incluído no texto original da Carta de 1988. Embora o tema tenha sido debatido, não se construiu maioria favorável à instituição de um órgão com atribuições de controle da atividade administrativa e do desempenho dos deveres funcionais do Poder Judiciário e do Ministério Público. O que se viu aprovado, portanto, foi um modelo constitucional que assegurava diversas garantias de independência ao Judiciário brasileiro, sem que mecanismos de controle e fiscalização adequados fossem previstos: o que se estabeleceu apenas foi a autonomia de cada tribunal para realizar sua gestão, e a aplicação de sanções disciplinares ficou à cargo de suas próprias corregedorias, que as realizam de modo fragmentado e pouco transparente (RAMOS e DINIS, 2009). Ao fazer um resgate da discussão acerca da criação de um Conselho Nacional de Justiça na Constituinte, Maluf (2013) resgata o fundamento dos argumentos contrários à sua criação: para os críticos, que acabariam por vencer o debate, um órgão dessa natureza representaria uma ameaça à autonomia e independência decisória dos juízes, com isso representando um enorme obstáculo para o exercício jurisdicional do Poder Judiciário qual seja, garantir os direitos e garantias individuais e sociais previstos na Carta - que requeriria uma atuação livre de pressões e controles externos. Talvez pela razão histórica de superar um regime autoritário e fornecer as bases da nova democracia, a 
Constituição de 1988 se ocupou muito mais em garantir a autonomia e a independência de órgãos e poderes, e menos de seus controles recíprocos e externos.

A independência judicial decisional, como já exposto, está intimamente relacionada com à proteção da imparcialidade e com a garantia da aplicação igualitária da lei, princípios essenciais ao Império da Lei, um dos pilares do Estado Democrático de Direito que se pretendeu atingir com a Constituição de 1988. Apesar de essencial ao Império da Lei, a independência judicial decisional, combinada com outras garantias dadas constitucionalmente ao Poder Judiciário no Brasil, como a autonomia financeiraadministrativa, a independência funcional e o ingresso na magistratura por meio concurso de provas e títulos e vitaliciedade no cargo - não sendo os magistrados portanto sujeitos a controle partidário ou eleitoral - levantam a clássica questão da accountability ${ }^{4}$ judicial: afinal, quem guarda os guardiões?

A definição conceitual de accountability é sujeita a divergências na literatura especializada, mas há um conceito mínimo compartilhado pelos autores que trabalham com essa temática de que a noção de accountability se refere, de maneira ampla, à fiscalização e responsabilização dos agentes públicos ${ }^{5}$. O’Donnell (1994) estabeleceu uma distinção entre dois tipos de accountability, usando como corte de distinção a origem ou de onde partia a exigência de prestação de contas sobre um determinado agente público. Essa distinção cristalizou duas categorias clássicas de accountability $^{6}$ : a vertical e a horizontal.

Denomina-se accountability vertical o conjunto dos mecanismos que possibilitam ações promovidas pela sociedade - na figura de seus cidadãos, órgãos de imprensa e organizações da sociedade civil - voltadas ao monitoramento e controle dos agentes públicos. Por accountability horizontal entende-se a fiscalização sobre um agente público exercida por um órgão do Estado (podendo ser de um órgão do mesmo poder constitucionalmente constituído ou de outro poder), com competências legais e institucionais de realizar a fiscalização, exigir prestação de contas e promover a responsabilização, através da aplicação de sanções, quando necessário.

No cenário pós-88, a questão da accoutability do Judiciário ganhou fôlego novamente. O debate sobre a necessidade de um órgão de controle externo ao Judiciário

\footnotetext{
${ }^{4}$ Para uma discussão mais exaustiva acerca de accountability judicial, ver Garoupa \& Ginsburg (2008), Geyh (2003), Ferejohn (1999)

${ }^{5}$ Para uma discussão mais aprofundada sobre as divergências conceituais acerca de accountability, ver Ceneviva (2006)

${ }_{6}^{6}$ Para uma discussão mais exaustiva sobre as categorias de accountability, ver O’Donnell (1994), SCHEDLER (1999)
} 
foi reintroduzido logo no início da década de 1990, em meio a agenda de reformas constitucionais, em que uma reforma judiciária também foi pautada. A nova carta constitucional ampliou sensivelmente o acesso à justiça no Brasil e estimulou a busca por direitos junto ao Judiciário, acarretando assim uma avalanche de processos. Por outro lado, este crescimento do volume de processos, associado à falta de modernização da estrutura judiciária, agravou o problema da morosidade da justiça e recolocou a questão da reforma do judiciário na ordem do dia. Nesse processo, questões como o desempenho dos magistrados, a transparência (melhor dizendo, a falta dela) dos tribunais, o anacronismo dos procedimentos administrativos, o excessivo número de recursos, dentre outras, passaram a ser problematizadas em meio ao debate sobre a “crise do judiciário" e seus impactos negativos sobre a sociedade, a segurança jurídica e a economia (Sadek e Arantes 1994; Sadek 2004, 2001; Pinheiro 2000)

A Proposta de Emenda Constitucional (PEC) 96/1992, apresentada ao Congresso Nacional pelo então Deputado Helio Bicudo (PT-SP), marcou o início dos debates sobre a reforma judiciária. Com o passar do tempo e das discussões, a PEC 96/92 foi agregando uma série de tópicos de reforma do sistema judiciário, que podem ser analiticamente enquadradas em três grandes eixos, segundo Arantes (2003): 1) propostas que procuraram lidar com o problema da jurisdição política constitucional; 2) propostas que lidaram com a questão do acesso à justiça - seja para sua ampliação ou para a sua redução e, finalmente, 3 ) propostas que giraram em torno dos mecanismos de controle e fiscalização dos órgãos do sistema de justiça, retomando o debate sobre a criação de um Conselho Nacional de Justiça - CNJ (SADEK, 2004). Interessa-nos, aqui, explorar brevemente o terceiro eixo - o da criação de um órgão de controle externo buscando reconstruir qual foi a concepção inicial desse órgão e como ela foi debatida e reformulada diversas vezes até chegar no modelo finalmente aprovado. Com essa reconstrução histórica breve, procuraremos analisar até que ponto o CNJ que temos hoje corresponde à ideia inicialmente concebida de órgão de controle externo do Judiciário e de que modo a sua definição como órgão de administração da justiça é fundamental para o desenvolvimento posterior de iniciativas como a analisada nessa dissertação, isto é, o Forum da Saúde.

A cronologia da reforma já nos dá um indicativo de quão controversos foram os debates: apresentada em 1992, a reforma só veio a ser aprovada pela Câmara dos Deputados em 2000, e pelo Senado, após passar por novas emendas, em 2004. A PEC 96/92 passou por seis grandes momentos de construção: a primeira fase ocorreu ainda 
sob a Revisão Constitucional de 1993-1994, cuja relatoria (geral da revisão) coube ao deputado Nelson Jobim. Embora os resultados dos esforços do relator sobre a matéria não tenham sido levados à votação, eles foram importantes para estabelecer as linhas gerais da reforma que pautariam a futura tramitação da PEC 92/96 (Arantes, 2003, 121). A segunda fase de tramitação da proposta ocorreu na legislatura de 1995-1999, tendo sido examinada na Comissão Especial sob a relatoria do Deputado Jairo Carneiro, que apresentou seu relatório em 1996, mas este sequer foi à votação na Comissão. As terceira e quarta fases, ainda na Câmara dos Deputados, ocorreram na legislatura de 1999-2003, com a reinstalação da Comissão Especial em 1999, tendo o Deputado Aloysio Nunes sido escolhido como relator. O deputado chegou a concluir seu relatório, cercado de muita controvérsia, em julho de 1999, mas a proposta não foi levada adiante porque o próprio relator fora nomeado para a Secretaria Geral da Presidência da República naquele mês, tendo sido substituído na relatoria da Comissão Especial por sua colega de partido, a Deputada Zulaiê Cobra. Sob a relatoria de Zulaiê Cobra, a PEC 92/96 entraria em sua quarta fase de tramitação para finalmente, mas não sem intensos e controversos debates, chegar a uma versão aprovada pela Câmara em junho de 2000. Enviada ao Senado, a quinta fase transcorreu sob a relatoria de Bernardo Cabral, tendo o projeto sido levado à votação e aprovado em primeiro turno no final da legislatura, em 2002. Retomando os trabalhos em 2003, sob a nova relatoria do senador José Jorge (porque Bernardo Cabral não se reelegera por seu estado), a sexta fase transcorreu até dezembro de 2004, quando finalmente o texto foi aprovado em segundo turno pelos senadores, resultando na Emenda Constitucional 45/2004. Em cada uma dessas fases e seus respectivos relatórios, um novo desenho de um rgão capaz de exercer o controle externo do Judiciário foi apresentado. Os maiores impasses, no entanto, ficaram menos em função de suas atribuições, e giraram mais em torno de sua composição. Em relação às atribuições, a resistência em relação à necessidade de um órgão de controle já havia sido consideralvelmente diminuída, tendo em vista a realidade pós-88 e a ampliação dos debates nesse sentido no Congresso, na sociedade e com forte apoio da mídia.

Dada a impossibilidade de resistir à introdução de um órgão de controle do Judiciário no bojo da reforma, o ponto de maior controvérsia nos diversos projetos apresentados ficou, então, na composição do órgão. Dois aspectos foram intensamente debatidos: a quantidade de membros que integrariam o Conselho e quem seriam esses membros, ou seja, de quais instituições eles viriam/representariam. A real natureza do organismo - se ele viria a se constituir num órgão de controle efetivamente externo ou 
se viria a se tornar um órgão de controle interno - dependia, em grande parte, da sua composição. A forma de seleção dos titulares, se por eleição ou indicação (e, nesse caso, a quem caberia indicá-los), também foi alvo de disputa. Abaixo, reproduzimos a tabela compilada por Sadek (2004), que sintetiza a composição proposta por cada um dos projetos até aquele aprovado pela Câmara dos Deputados, e a proporção de membros externos em relação ao total de membros:

\section{Figura 1 - Composição do Conselho Nacional da Justiça nas diferentes propostas da Câmara dos Deputados (não inclui Senado nem a definição final)}

Composição do Conselho Nacional da Justiça segundo as propostas analisadas (n.d membros/externo).

\begin{tabular}{|l|c|c|}
\hline \multicolumn{1}{|c|}{ Projeto de Reforma } & Total de membros & Membros Externos \\
\hline Jairo Carneiro & 15 & 2 \\
\hline Aloysio N. Ferreira & 9 & 3 \\
\hline Zulaiê Cobra & 13 & 6 \\
\hline Comissão & 14 & 6 \\
\hline Câmara Deputados & 15 & 6 \\
\hline
\end{tabular}

Fonte: A Reforma do Judiciário, SADEK (2004)

A proposta aprovada pela Câmera dos Deputados, e posteriormente pelo Senado - sem emendas - acabou tornando o Conselho um ógão composto por 15 membros com mandatos de 2 anos cada, com uma possível recondução. Do total de 15 membros, 9 são magistrados e 6 são membros não-magistrados ${ }^{7}$, muito embora pertencentes a carreiras jurídicas. Conforme afirma Fragale Filho (2013), um conselho assim constituído afastaria a hipótese de um controle verdadeiramente externo. Assim mesmo, a Associação dos Magistrados Brasileiros (AMB) investiu contra a sua instalação por meio da Ação Direta de Inconstitucionalidade 3367, argumentando que a criação do conselho ofendia o princípio da separação de poderes. O STF não atendeu o pedido da $\mathrm{AMB}$, mas não pelas razões esperadas: o tribunal afirmou que o órgão não era de controle externo, mas integrava o próprio Judiciário e assim não poderia ser visto

\footnotetext{
${ }^{7}$ Compõem o CNJ: (i) Ministro do STF indicado pelo tribunal, (ii) Ministro do Superior Tribunal de Justiça (STJ) indicado pelo STJ, que será corregedor de justiça; (iii) Ministro do Tribunal Superior do Trabalho (TST) indicado pelo tribunal; (iv) Desembargador de um dos Tribunais de Justiça (TJ) indicado pelo STF; (v) Juiz estadual indicado pelo STJ; (vi) Juiz do Tribunal Regional Federal (TRF) indicado pelo STJ; (vii) Juiz federal indicado pelo STJ; (viii) Juiz de um Tribunal Regional do Trabalho indicado pelo TST; (ix) Juiz do trabalho indicado pelo TST; (x) membro do Ministério Público da União indicado pelo Procurador Geral da República; (xi) membro do Ministério Público estadual, escolhido pelo Procurador Geral da República e indicado pelos ministérios públicos estaduais; (xii) dois advogados indicados pelo Conselho Federal da OAB; (xiii) dois cidadãos de notável saber jurídico e moral ilibada, sendo um indicado pela câmara dos deputados e outro pelo Senado Federal.
} 
como uma ameaça à separação de poderes. A confirmar essa nova arquitetura institucional, que não corrigia o déficit democrático do judiciário (Fragale Filho, 2013), as presidências dos dois órgãos de cúpula da organização judiciária brasileira - o STF e o CNJ - seriam ocupadas pelo mesmo ministro sendo que, na sua ausência no caso do CNJ, assume o vice-presidente do STF e não um eventual vice do próprio Conselho. Os demais membros, embora sejam nomeados pela Presidência da República, depois de aprovação pela maioria absoluta do Senado Federal, são inicialmente indicados pelos próprios tribunais com os quais guardam correspondência. Esse mix de estratégias de indicação e nomeação buscou equilibrar a finalidade de controle com a autonomia do judiciário frente aos demais poderes.

Entre as competências do CNJ estão a de estabelecer alguns padrões e diretrizes nacionais para o funcionamento dos tribunais, especialmente no que se refere à administração de recursos humanos e financeiros, à informatização e à gestão de informações. Outra de suas atribuições é a de planejamento estratégico dos tribunais, para atender a necessidade de coordenação do campo de atuação do Judiciário, dado que o Judiciário brasileiro é composto por diversos tribunais, cada um deles dotado de autonomia administrativa e financeira, sem atuação uniforme entre si. O CNJ tem o poder de emitir resoluções e recomendações, com vistas a cumprir seus objetivos. No entanto, tais instrumentos não têm caráter vinculativo.

Por suas competências, a accountability horizontal exercida pelo CNJ, enquanto órgão judiciário, abarca questões administrativas e comportamentais dos magistrados, mas não tem competência ou atribuições específicas que lhe permitam exercer uma revisão das decisões propriamente judiciais, isto é, exercer algum tipo de controle externo à independência decisional dos juízes. Seja pela composição majoritariamente interna à própria justiça, seja pelo rol de atribuições que lhe foram conferidas, o CNJ acabou por se converter mais num órgão de administração da justiça do que em controle externo do Judiciário. No processo que levou à sua afirmação como órgão de governança judiciária, o CNJ se viu igualmente suscetível às mudanças de estilos de seus presidentes, graças à variação de perfil dos próprios ministros do STF que presidiram o Conselho desde sua instalação. Seu caráter administrativo e não judicial, todavia, permitiu-lhe iniciar reformas importantes no funcionamento do judiciário, visando sua modernização. Se a dimensão do controle disciplinar da magistratura não alcançou o nível que muitos esperavam, por outro lado, o CNJ veio se notabilizando por introduzir programas e políticas nas mais diversas frentes de atuação 
da própria justiça, configurando o que Arantes (2015) denominou de "políticas públicas da justiça." Hoje, o CNJ lidera iniciativas nas áreas de conflitos fundiários, trabalho escravo, tráfico de pessoas, violência doméstica e intrafamiliar contra a mulher, organiza o Cadastro Nacional de Adoção, sustenta a Estratégia Nacional de Combate à Corrupção e à Lavagem de Dinheiro (Enccla), desenvolve programas de estímulo à conciliação e mediação, de gestão dos precatórios junto aos tribunais, sedia a Estratégia Nacional de Justiça e Segurança Pública para o combate à violência (Enasp), atua por meio de diversas iniciativas para melhorar as condições do sistema prisional brasileiro, dentre outras políticas públicas da justiça ${ }^{8}$. O Fórum da Saúde, que examinaremos mais adiante, é uma dessas iniciativas.

\subsection{O direito à saúde no Brasil: Constituição de 1988 e pós-88}

\subsubsection{Estabelecendo o Direito à Saúde: A constituição de 1988}

A constituição de 1988 se tornou célebre por ter consagrado uma série de direitos, não apenas os clássicos direitos civis de liberdade e políticos de participação, mas também direitos sociais nas mais diversas esferas. Mas foi na área da saúde, especialmente porque incluiu um novo desenho institucional para a política ser planejada e implementada nessa área - o Sistema Único de Saúde - que a constituição deu o seu passo mais radcial à luz da trajetória de direitos sociais no Brasil. Essa trajetória sempre foi marcada pela segmentação em diferentes tipos de acessos e de responsabilização fragmentada entre órgãos e instituições.

A política de saúde pública no Brasil desenvolveu-se dentro de um sistema de proteção social, construído a partir dos anos 30. A seguridade social era oferecida por dois modelos distintos: o modelo de seguro social oferecido através da área previdenciária - o que incluia a assistência à saúde - que abrangia a população inserida no mercado de trabalho formal; e o modelo assistencial, direcionado à parcela da população que se encontrava excluída do mercado formal de trabalho.

Teixeira (2009) resume o modelo assistencial como aquele em que "as ações são de caráter emergencial, estão dirigidas aos grupos de pobres mais vulneráveis, e inspiram-se em uma perspectiva caritativa e reeducadora. Estas ações organizam-se com base na associação entre trabalho voluntário e políticas públicas, estruturam- se de forma pulverizada e descontínua, gerando organizações e programas muitas vezes

\footnotetext{
${ }^{8}$ Tais programas e política podem ser conhecidos em http://www.cnj.jus.br/programas-e-acoes
} 
superpostos" (TEIXEIRA, 2009, pag 473). O modelo de seguro social pela área previdenciária não era menos fragmentado: cada grupo ocupacional tinha seu próprio instituto de seguridade e tipo de cobertura à saúde, e o usufruto dessa assistência pelos beneficiários dependia tanto do pertencimento às categorias ocupacionais que eram autorizadas a operar um seguro quanto das contribuições previdenciárias aos seguros específicos. Dessa forma, a assistência à saúde se configurava menos como um direito social e mais como uma relação de direito contratual, que criou privilégios diferenciados baseados em categorias ocupacionais. Wanderley Guilherme dos Santos (1979) denomina essa estrutura de "cidadania regulada" pela condição de trabalho e da categoria profissional, justamente por serem o trabalho e a profissão os intermediários necessários para se usufruir de proteção social - e mesmo assim, de forma bem diferenciada mesmo entre os trabalhadores com vínculos trabalhistas formais.

Esse modelo, contruído nos anos 1930, manteve-se pelas décadas seguintes. Mesmo incorporando grupos antes não reconhecidos, como trabalhadores rurais e empregadas domésticas, a proteção social seguiu sendo altamente fragmentada e não universal, mantendo a relação de trabalho como via de acesso à assistência à saúde. A luta pela redemocratização, que ganhou tração na década de 1970, tinha como demandas centrais da agenda uma organiação social que privilegiasse a inclusão social e a equidade. Em torno dessas ideias, e como parte da luta pela democracia, organizou-se o Movimento Sanitário Brasileiro, que também ficou conhecido como sanitarismo, que tinha como reivindicação principal a reconfiguração do modelo de proteção social no país. Em contraposição com o modelo então vigente, o modelo proposto buscava romper com a lógica de coberturas diferenciais e restritas a grupos inseridos no mercado formal de trabalho, além de quebrar com a noção de que a saúde era um benefício a ser usufruído por contribuintes, colocando a saúde na chave de direito social, o que implica dizer que a saúde deveria passar a ser dever do Estado. O modelo buscado pelo movimento sanitarista também se baseava em um princípio sanitário que entende que a proteção à saúde deve ser garantida de forma integral, passando pela prevenção, tratamento em todos os níveis de complexidade de doenças, e reabilitação.

O movimento sanitarista foi vitorioso em estabelecer um outro modelo de proteção social inaugurado com o retorno à democracia: o direito à saúde foi reconhecido como um direito social dos cidadãos e o um dever do Estado pela 
Constituição Federal de 1988 em seu artigo $196^{9}$. A Constituição também criou, em seu artigo $198^{10}$, o Sistema Único de Saúde (SUS), como forma de organizar e dar concretude ao direito à saúde no Brasil. O SUS tem como diretrizes o atendimento integral, igualitário e universal para toda a população, atualmente em cerca de 208 milhões de habitantes ${ }^{11}$. O princípio da universalidade significa que não haverá barreiras financeiras ou de titularidades pré-definidas com base em critérios corporativos ou de qualquer outro tipo para que os indivíduos tenham acesso aos cuidados de saúde; o princípio da integralidade significa que os indivíduos devem receber cuidados adequados em todos os níveis da complexidade de uma doença.

A Constituição de 1988 também estabeleceu que todos os entes federados teriam responsabilidades na execução das políticas públicas de saúde, estabelecendo inclusive níveis mínimos de investimento para o de financiamento da saúde para cada nível de governo: os municípios precisam investir anualmente pelo menos $15 \%$ dos seus orçamentos em políticas públicas de saúde, e os estados um mínimo de $12 \%$. A União deve investir $15 \%$ de seu orçamento ${ }^{12}$.

A pergunta que decorre desses artigos da CF-88 é: como de fato organizar e implementar o direito à saúde, tal como previsto constitucionalmente, traduzindo-o em políticas públicas governamentais e serviços entregues à população, incluindo os três níveis de governo na efetivação do direito à saúde?

\subsubsection{Dando concretude ao direito à Saúde: as normas infra-constitucionais}

O Sistema Único de Saúde (SUS), conforme previsto na Constituição de 88, foi regulamentado pelas Leis Orgânicas da Saúde $^{13}$, que buscaram organizar o funcionamento dos serviços de saúde oferecidos pelo sistema público de saúde, em todo território nacional. Apesar de dar ênfase à descentralização político-administrativa do SUS, na forma da municipalização dos serviços e ações de saúde, sua organização é tripartite. Esse arranjo institucional complexo, como veremos a seguir, foi a saída

\footnotetext{
9 "A saúde é um direito de todos e dever do Estado, garantido mediante políticas sociais e econômicas que visem à redução do risco de doença e de outros agravos e ao acesso universal e igualitário às ações e serviços para sua promoção, proteção e recuperação" (BRASIL, 1988)

10 “É prevista ainda a constituição de um sistema único para prover as ações e serviços de saúde, que tem como diretrizes o atendimento integral, igualitário e universal” (BRASIL, 1988)

${ }^{11}$ IBGE, http://www.ibge.gov.br/apps/populacao/projecao

${ }^{12}$ Meta a ser atingida em 2018, de acordo com a EC 86/2015.

${ }^{13}$ Leis $8.080 / 1990$ e $8.142 / 1990$
} 
encontrada para garantir a coordenação dos três níveis de governo (União, estados e municípios) na formulação e concretização das políticas de saúde, visto que todos os entes federados têm responsabilidades no que diz respeito à concretização do direito à saúde, na forma de políticas públicas.

Em termos gerais, os municípios têm a responsabilidade de prestar serviços de saúde de baixa e média complexidade com o apoio dos estados e da União. Os estados, por sua vez, são geralmente responsáveis pelos serviços de média e alta complexidade, com apoio da União. O Ministério da Saúde, no nível federal, é responsável pela elaboração, auditoria, monitoramento, controle e avaliação da implementação e execução das políticas públicas de saúde pelos estados e municípios.

No entanto, as responsabilidades de cada ente federado são, via de regra, definidas em políticas públicas e acordos alcançados em fóruns decisórios próprios do SUS, quais sejam: i) CIB (Comitê Intergestores Bipartite), com escopo estadual, que reúne autoridades sanitárias dos municípios daquele estado (COSEMS - Conselho de Secretarias Municipais de Saúde) e a secretaria de saúde do estado; e ii) o CIT (Comitê Intergestores Tripartite), que reúne autoridades sanitárias dos municípios, representados em um nível central (CONASEMS - Conselho Nacional de Secretarias Municipais de Saúde), autoridades sanitárias dos estados (CONASS - Conselho Nacional de Secretários de Saúde) e do nível federal, com representantes do Ministério da Saúde.

No que tange o financiamento do sistema público de saúde, apesar de a Constituição ter determinado percentuais mínimos de investimento nas políticas de saúde para cada ente federado, na prática, estados e municípios, além de seus investimentos mínimos, recebem recursos transferidos da União, e os municípios também recebem recursos transferidos dos estados, numa estrutura complexa de orçamentos que dependem de políticas públicas acordadas nas instâncias decisórias do SUS.

Essa organização extremamente complexa do SUS espelha a complexidade das ações e serviços que, seguindo o princípio da universalidade, precisam ser oferecidos a toda população de maneira uniforme: o cidadão de uma cidade no interior do Acre deve ter acesso ao mesmo rol de ações e tratamentos que o cidadão na cidade de São Paulo. Para que isso seja possível, a articulação e cooperação entre todos os entes federados, todos solidariamente responsáveis pela concretização do direito à saúde, é essencial.

Além do desafio de uniformizar as políticas públicas de saúde em um país continental e extremamente desigual, que conta com mais de 5.000 munícipios com 
capacidade de formulação e entrega de serviços públicos muito distintas, o SUS tem outro grande desafio: atender ao princípio da integralidade. A interpretação do que esse princípio de fato significa na prática é alvo de disputas, mas oferecer tratamento integral para os cidadãos tem sido historicamente interpretado pelas cortes como a obrigação do Estado de oferecer qualquer tratamento necessário para manejar uma situação de saúde de um cidadão, em qualquer grau de complexidade.

O rápido avanço das tecnologias em saúde ${ }^{14}$, combinado com o princípio da integralidade, tem pressionado o sistema público de saúde. A perspectiva de incorporação oficial no SUS de medicamentos e procedimentos cada vez mais caros a serem ofertados para toda a população, além da sempre possível necessidade de prover tratamentos não oficialmente incorporados no Sistema, tem tido impactos tanto financeiros, como organizacionais, quando pensamos que qualquer cidadão pode demandar, pela via judicial, um tratamento a qualquer nível de governo, o que traz abalos às políticas públicas estruturadas nas instâncias governamentais responsáveis pelo SUS, principalmente pela necessidade de realocação de recursos para atender demandas judiciais, não previstas em orçamento.

Em vista disso, o Estado tem tentado oferecer uma outra interpretação do que significaria o princípio da integralidade. Um movimento importante nessa direção foi a criação da CONITEC - Comissão Nacional de Incorporação de Novas Tecnologias, através da Lei $n^{\circ}$ 12401/2011, que por meio da regulamentação do conceito de integralidade, visa estabelecer limites e condições ao direito subjetivo à saúde. A CONITEC é coordenada pelo Ministério da Saúde, mas tem em sua composição representantes do CONASS, CONASEMS, Agencia Nacional de Vigilância Sanitária (ANVISA), Agência Nacional de Saúde Suplementar (ANS), representantes do próprio Ministério da Saúde e do Conselho Federal de Medicina (CFM). A principal atribuição dessa Comissão é realizar análises custo-efetividade e segurança de tecnologias de saúde, numa análise baseada em evidências científicas, e recomendar ou não sua incorporação no rol de tratamentos ofertados pelo SUS, além de indicar em que situações de saúde as tecnologias incorporadas devem ser usadas, através da constituição e alteração de Protocolos Clínicos e Diretrizes Terapêuticas (PCDTs).

\footnotetext{
${ }^{14}$ A Organização Mundial de Saúde define Tecnologia em Saúde como” a aplicação de conhecimentos e habilidades organizados na forma de dispositivos, medicamentos, vacinas, procedimentos e sistemas desenvolvidos para resolver um problema de saúde e melhorar a qualidade de vida". http://www.who.int/topics/technology_medical/en/
} 
Apesar de fazer análises de custo-efetividade, a CONITEC não adota um limiar máximo para os custos, dado que isso iria contra o princípio da integralidade do SUS, previsto constitucionalmente.

\subsection{Conclusão: A possibilidade de judicialização de direitos no Brasil: Constituição de 1988 e pós-88}

Inserindo-se no contexto do novo constitucionalismo latino-americano, a Constituição Federal Brasileira de 1988 deu ênfase à promoção de direitos sociais, indo além da afirmação do império da lei e da proteção de direitos individuais, típicas do constitucionalismo liberal do século XIX. A elevação do direito à saúde a um direito constitucional, e sua transformação de um direito exclusivamente social a um direito também individual, é um marco da mentalidade que presidiu a feitura da nossa atual Constituição, em um contexto de retorno a um Estado Democrático de Direito.

Em democracias que adotaram constituições que se inserem no "novo constitucionalismo" (NOLTE E SCHILLING-VACAFLOR, 2012) eque emergiu no pós II Guerra Mundial, em que status constitucional foi dado a um amplo conjunto de direitos substantivos, e mecanismos de revisão constitucional e apreciação judicial desses direitos são previstos, as diversas instâncias do Poder Judiciário tem tanto incentivos quanto instrumentos para influenciar os resultados de políticas públicas. Stone Sweet (2000) argumenta que o controle constitucional em contextos de direitos substantivos constitucionalizados deposita nos juízes um papel que vai além de uma proteção de liberdades fundamentais, uma vez que a Constituição, nesses contextos, também assegura a satisfação desses direitos substantivos, implicando em obrigações positivas do Estado.

Nessas circunstâncias, a autoridade para decidir qual a natureza, escopo e relação de um dado direito com o resto do texto constitucional é transferida aos juízes, que com isso adquirem um grande potencial de impactar a formulação de políticas (STONE SWEET, 2000, p. 58).

Além disso, no caso brasileiro, como o controle de constitucionalidade adotado combina elementos de controle concentrado-abstrato e difuso-concreto, caracterizado como híbrido por Arantes (1997), as oportunidades de o Judiciário ser chamado a resolver conflitos concernentes a políticas públicas e direitos substantivos são ampliadas. Soma-se a isso o estabelecido pelo artigo $5^{\circ}$, inciso XXXV, da CF-88, que 
prevê que o Poder Judiciário não poderá deixar de apreciar qualquer ação que reivindique a tutela de qualquer direito.

Portanto, na falta de políticas públicas elaboradas pelo Executivo e pelo Legislativo que assegurem um determinado direito constitucionalizado, atores legitimados pela constituição, o que inclui cidadãos que levam seus pleitos à Justiça Comum, podem demandá-lo pela via judicial. No caso específico dos litígios acerca do direito à saúde, tais pleitos podem ser julgados em todos os aparelhos da Justiça Comum, podendo chegar até o Supremo Tribunal Federal pela via do Recurso Extraordinário (RE), uma vez que o direito à saúde no Brasil é um direito constitucional. Isso significa dizer que as centenas de juízos de primeira instância, os 27 tribunais de segunda instância estaduais e o do Distrito Federal (Tribunal de Justiça), os 5 tribunais de segunda instância federais (Tribunal Regional Federal), o Superior Tribunal de Justiça (STJ) e o Supremo Tribunal Federal (STF) podem analisar ações que tenham o direito à saúde como base de seus pedidos. 


\section{JUDICIALIZAÇÃO DO DIREITO À SAÚDE NA LITERATURA BRASILEIRA}

\subsection{Houve uma judicialização do direito à saúde no Brasil? O ciclo da judicialização}

Com a nova distribuição dos poderes formais e o papel do Judiciário no sistema constitucional inaugurado pela constituição de 1988, as ciências sociais e jurídicas se ocuparam de analisar a judicialização da política no caso brasileiro. De forma ampla, a literatura lança mão da expressão "judicialização da política" para se referir a um alargamento do escopo de atuação do Poder Judiciário para áreas não originalmente suas, mas que caberiam aos poderes Executivo e Legislativo, em especial quando as ações trazidas a julgamento demandam decisões que podem acarretar a limitação ou alteração de políticas públicas ou decisões políticas colocadas em marcha pelos outros poderes. Esse fenômeno não estaria restrito ao Brasil, mas poderia ser verificado, em maior ou menor grau, em todos os Estados Democráticos de Direito.

Na ciência política, a noção de judicialização da política foi inaugurada por Tate e Vallinder (1995), que elaboraram o conceito para explicar o fenômeno em um conjunto de países examinados no livro. Para os autores, poder-se-ia falar em judicialização quando o julgamento de ações que envolvessem políticas governamentais e a utilização de procedimentos jurídicos na ordenação do mundo político fossem verificados, aliados a uma postura politicamente ativa dos juízes. Os estudos acerca dessa temática passaram por fases, a primeira de identificação da ocorrência ou não da judicialização da política baseada nas prerrogativas do poder Judiciário e na matéria das ações que a ele chegavam. Parte da literatura, principalmente do Direito, buscou analisar, do ponto de vista principiológico, se a judicialização da política figurava ou não uma intromissão do poder Judiciário sobre as competências dos outros poderes constitucionalmente constituídos, de forma a qualificar sua ocorrência como positiva ou negativa para o regime republicano instituído pela CF- 88 .

Uma outra fase foi inaugurada, principalmente por estudos da Ciência Política, em que a preocupação maior girava em torno de mensurar empiricamente a judicialização da política e caracterizar os tipos do fenômeno e seus impactos para o funcionamento do sistema político. O que os estudos dessa última fase argumentavam é que um dos dois elementos elencados ainda em 1995 por Tate e Vallinder para 
conceituar o fenômeno, a postura politicamente ativa dos juízes, não estava sendo adequadamente considerada pelos primeiros trabalhos de caracterização do fenômeno. Ao não observarem conjuntamente os dois elementos propostos por Tate e Vallinder, os estudos anteriores esqueceram-se do fato de que apenas o acionamento do Judiciário para a resolução de conflitos que envolvessem políticas governamentais não é condição suficiente para a ocorrência de judicialização da política; é necessário verificar se houve resposta judicial às ações propostas "contrária àquela predominantemente nas instituições majoritárias, opondo-se, assim, às políticas por estas adotadas" (Oliveira, 2005, p.564). Para tal verificação, análises de base empírica seriam condição sine qua non de estudos que pretendessem atestar ou não a ocorrência e descrever a magnitude da judicialização da política.

Para tornar mais clara a distinção das etapas necessárias à ocorrência do fenômeno, Oliveira (2005) introduz a noção de ciclo de judicialização, o qual, para se completar, requereria três fases distintas: i) a politização da justiça - que designaria o acionamento do Judiciário para a resolução de conflito de ordem política; ii) o julgamento do pedido de liminar, se houver; iii) e, por fim, a judicialização da política propriamente, que se caracterizaria pelo julgamento do mérito da ação, de modo a alterar ou interferir no status quo vigente. Em sua pesquisa acerca das privatizações levadas a cabo nos anos 1990 no Brasil, a autora conclui que não há que se falar em judicialização no caso das privatizações, pois apesar de um grande numero de ADIs impetradas, o Judiciário não julgou o mérito de tais ações e, portanto, não teve efeito sob o status quo vigente da política de privatizações. Embora concentrado no caso das privatizações, o esquema de Oliveira se mostrou útil para esclarecer que o fenômeno pode se dar na primeira etapa, pode ir à segunda (liminares), mas nem sempre é confirmado na última, qual seja, a de efetiva reversão da decisão do Executivo.

Para o interesse desse trabalho, cabe-nos estabelecer se houve efetiva judicialização do direito à saúde no Brasil, ou seja, se i) o Judiciário foi chamado a se pronunciar em ações acerca de políticas governamentais sobre o direito à saúde e ii) se houve uma postura politicamente ativa dos juízes, entendida como o proferimento de decisões contrárias às leis e políticas adotadas pelos poderes Legislativo e Executivo.

O direito à saúde é o que perfaz o tema da maioria das ações que chegam ao Judiciário dentre o conjunto de ações que demandam direitos sociais pela via da justiça comum (Fanti, 2009). Essas ações, apoiadas no direito à Saúde, conforme estabelecido pela constituição e discutido no capítulo anterior, pleiteiam acesso a tratamentos e 
tecnologias de saúde custeadas pelo poder público, mais especificamente pelo Sistema Único de Saúde, que por diferentes motivos não estão sendo fornecidos pelas políticas governamentais vigentes ${ }^{15}$. Nesse sentido, a politização da justiça para a resolução de conflitos acerca do direito à saúde de fato ocorre.

Resta verificar se, para além da politização, houve também intensa judicialização do direito à saúde, ou seja, se afora o recorrente acionamento do Judiciário para resolver conflitos envolvendo o direito previsto constitucionalmente, os resultados práticos dos julgamentos de mérito dessas ações foi uma interferência do Judiciário nas políticas de saúde.

A literatura que se dedica a estudar a chamada judicialização do direito à saúde se concentra principalmente em dois campos do conhecimento: no Direito e na Saúde Pública. Por esse motivo, optamos nesse trabalho por adotar o termo "judicialização do direito à saúde" no sentido definido por Oliveira e Noronha (2011), que unifica as características enfatizadas pelas duas literaturas principais que estudaram o fenômeno: o Direito (direito à saúde) e a Saúde Pública (judicialização da saúde) (OLIVEIRA E NORONHA, 2011, p. 11).

Apesar de analisarem o mesmo fenômeno, as duas disciplinas partem de abordagens distintas: enquanto o campo do Direito costuma concentrar-se na discussão da legitimidade democrática do Judiciário para tomar decisões sobre políticas públicas e de como a efetivação de um direito social pela via judicial causa impacto sobre o seu caráter coletivo, o campo da Saúde Pública se dedica mais ao debate sobre a capacidade (ou falta dela) do Judiciário em tomar decisões que são, para essa disciplina, técnicas e complexas e que deveriam ser resolvidas por especialistas em saúde por meio de políticas públicas.

Mesmo olhando o fenômeno por óticas distintas, as duas literaturas parecem concordar que existe um modelo brasileiro de judicialização do direito à saúde ${ }^{16}$. caracterizado pela prevalência de ações individuais, que demandam tratamento medicamentoso na grande maioria das vezes, e por uma altíssima taxa de sucesso para o propositor da ação (Ferraz e Vieira, 2009). Retomando o conceito de ciclo de judicialização, que implica, primeiramente, na politização da justiça (acionamento do Judiciário), passando pelo julgamento de liminar e, finalmente, no julgamento do mérito

\footnotetext{
${ }^{15}$ A caracterização mais exaustiva dessas ações será feita no capítulo seguinte desse trabalho.

${ }^{16}$ King (2012) diz se tratar de um modelo latino-americano de judicialização da saúde.
} 
da ação - o que configura a judicialização da política propriamente dita, há consenso entre as literaturas de que cada uma das fases do ciclo é efetivada para o caso do direito à saúde no Brasil. Estudos que optaram por abordagens empíricas do fenômeno confirmam tal caracterização (Marques e Dallari, 2006; Pepe et al., 2010; Biehl et al., 2012; Fanti, 2009), apontando ainda que a maior parte das demandas por medicamentos a partir dos anos 2000 se refere a produtos não incorporados ao SUS, isto é, não fornecidos através da Política de Assistência Farmacêutica. Uma pequena parcela dessas ações solicita o provimento de medicamentos não só não incorporados ao SUS como ainda não registrados na ANVISA, agência responsável pela análise de segurança e eficácia dos medicamentos (Chieffi e Barata, 2009).

As milhares de ações que chegam ao Judiciário através da justiça comum podem ser recebidas e processadas por diversos canais. Como não há um monitoramento centralizado das demandas e do impacto (orçamentário ou de outra ordem) nem pelas autoridades de saúde, nem pelo Judiciário brasileiro ${ }^{17}$, é difícil se chegar a números precisos. Os trabalhos que se propuseram a estudar empiricamente o fenômeno circunscreveram sua análise a municípios ou estados específicos, dada a dificuldade de sistematizar dados mais gerais. No entanto, quando olhamos de maneira conjunta para esses trabalhos, é possível a caracterização mais ampla do fenômeno: os juízes, ao serem chamados a arbitrarem esse conflito de ordem política, decidem sistematicamente contra o status quo vigente, alterando os rumos da política pública de saúde, conforme veremos a seguir.

\subsection{Organizando o debate: caracterizando a judicialização do direito à saúde no Brasil}

A judicialização do direito à saúde no Brasil ganhou impulso no início dos anos 1990, com portadores de AIDS demandando o fornecimento anti-retrovirais quando ainda não havia uma política pública voltada ao tratamento da doença, e seu fornecimento não era regular pelo Ministério da Saúde. Messender, Osório-de-Castro e Luiza (2005) analisam ações entre 1991 a 2002 propostas contra a Secretaria de Estado de Saúde do Rio de Janeiro e conseguem captar bem o início e evolução do caráter das ações e das respostas das cortes. Até 1998, 90\% das ações que demandavam medicamentos se referiam a anti-retrovirais. Esse tipo de medicamento deixa de ser o

\footnotetext{
${ }^{17}$ Veremos, mais a frente, que o Fórum da Saúde tem como ambição implantar um sistema de monitoramento centralizado.
} 
principal tema das ações quando sua distribuição torna-se garantida pela política nacional de DST/AIDS, mas a alta taxa de sucesso dessas ações abriu precedente para que outros tipos de medicamentos fossem demandados judicialmente. A partir dos anos 2000, o foco principal das demandas passa a ser medicamentos não incorporados ao SUS e de alta tecnologia. A diversidade de doenças e medicamentos pleiteados nas ações aumentou, mas o padrão de decisão das cortes permaneceu o mesmo, concedendo os pedidos na maior parte das ações (Scheffer, Salazar e Grou, 2005). Nesse mesmo sentido vão os achados da pesquisa de Marques e Dallari (2007), que analisam em profundidade 31 ações pleiteando medicamentos de 1994 a 2004 interpostas contra o Estado de São Paulo. A mudança no padrão dos temas dos processos também é identificada, assim como a característica dessas ações virem de autores individuais (100\% das ações analisadas) e a alta taxa de sucesso dos pleiteantes (acima de 90\%).

O crescente impacto que essas decisões têm no orçamento das esferas federativas condenadas também é ressaltado pela literatura dos dois campos de estudo. De acordo com dados do Ministério da Saúde, em 2005, este foi citado em 387 ações, que acarretaram R \$ 2,4 milhões para atender essas três centenas de pacientes. Em 2011, foram 7.200 ações, e o montante gasto para cumprir essas demandas judiciais aumentou cem vezes, chegando a R \$ 243 milhões. Apesar de não haver dados sistematizados para todos os estados e municípios sobre os gastos no atendimento de demandas judiciais relacionadas à saúde, alguns estudos de caso apontam o impacto no orçamento para algumas dessas esferas federativas, concluindo que o montante gasto para cumprir com as decisões judiciais em relação aos orçamentos das secretarias de saúde é sempre alto ${ }^{18}$, consumindo, por vezes, quase a totalidade dos recursos disponíveis para programas em saúde no caso de alguns municípios, de acordo com survey conduzido no nível municipal por Ferraz (2011).

No campo da saúde pública, há uma visão predominantemente negativa a respeito da atuação do Judiciário no tema. A principal crítica apontada por esses trabalhos é que as cortes não têm levado em conta as políticas públicas de saúde ao se manifestar quase sempre a favor do paciente, independentemente de qual medicamento está sendo demandado e para qual condição clínica. A razão para isso seria o desconhecimento, por parte dos juízes, das políticas públicas da área, sejam elas as

\footnotetext{
${ }^{18}$ Pode-se citar como principais trabalhos que procuram mensurar o impacto financeiro da judicialização do direito à saúde no nível estadual Machado et al (2011), Castro (2016), e Pereira et al. (2010).
} 
normas técnicas produzidas pelo Executivo, as listas de medicamentos oferecidos pelo SUS e os respectivos critérios clínicos para inclusão de novo medicamento e indicação de seu uso de acordo com os Protocolos Clínicos e Diretrizes Terapêuticas do Ministério da Saúde. A não observância desses fatores pelas cortes geraria distorções nas políticas públicas, como a obrigação de fornecer um medicamento não incorporado na Assistência Farmacêutica para uma determinada doença que dispõe de alternativa terapêutica no SUS e a dificuldade de gestão dos recursos disponíveis para as políticas de saúde, uma vez que cumprir com as demandas judiciais implica em realocação de recursos previstos originalmente para outros fins. Nesse sentido, Borges (2007), ao analisar ações judiciais que demandavam o fornecimento de medicamentos interpostas ao Estado do Rio de Janeiro em 2005, conclui que o Judiciário, através de suas decisões, tem tomado "verdadeiras decisões políticas sobre alocação de recursos" (p. 81-88), sem observar, no entanto, se os recursos alocados se destinam às questões prioritárias definidas pelas políticas públicas específicas. É importante ressaltar que o motivo principal apontado por essa literatura seria a incapacidade institucional do Judiciário, que, diferentemente do Executivo, não estaria tecnicamente preparado para avaliar a real necessidade e impacto que o medicamento demandado teria na condição clínica do paciente e tampouco conseguiria mensurar o impacto mais amplo de suas decisões na dimensão política.

Um primeiro grupo de estudos do campo do Direito interpreta o padrão de decisões do Judiciário no tocante à assistência à saúde como positivo, pois enfatiza que a garantia desses direitos pelo Judiciário, na ausência de sua efetivação pelo Executivo e pelo Legislativo, melhora a qualidade da democracia. A concepção de uma representação mais ampla na democracia, que extrapola a representação eleitoral tradicional e amplia a possibilidade de participação dos cidadãos na arena de decisões de caráter político pela via judicial é enfatizada para sustentar a visão positiva da judicialização de direitos sociais. Esses estudos se dedicam mais à discussão normativa do que a análises empíricas do teor das decisões e dos impactos que elas geram nas políticas públicas, como fazem os autores do campo de Saúde Pública, além de não considerarem em suas análises como se dá a organização do Judiciário em torno do tema.

A visão sobre o tema no campo do Direito não é, todavia, homogênea. Embora minoritários, há quem questione a legitimidade democrática do Judiciário para tomar decisões sobre políticas de saúde. Barcellos (2010) aponta que as decisões judiciais têm 
implicação em alocações de recursos e argumenta que a decisão de como gastar recursos públicos deveria ser atribuição exclusiva de representantes democraticamente eleitos, e, portanto, caberia apenas a membros do Executivo e do Legislativo. Em linha com outras pesquisas ${ }^{19}$, a autora também põe em tela a questão de que o direito à saúde é um direito coletivo, mas que se torna individual quando garantido por meios judiciais, uma vez que a decisão vale somente para o autor da ação. Os autores dessa vertente defendem que não é possível colocar direitos sociais no mesmo patamar de direitos civis, considerando que os primeiros não seriam direitos exigíveis.

No campo da ciência política, os estudos que investigam o uso da Justiça para demandas de direitos sociais, em especial as que dizem respeito ao direito a saúde, ainda são incipientes. Os autores que se dedicaram a analisar a temática dentro desse campo de estudo procuram analisar os efeitos das condenações nas políticas de saúde, ou seja, como as decisões judiciais provocam respostas do Executivo e moldam as políticas públicas (Fanti, 2009; Oliveira e Noronha, 2011; Carvalho, 2013). Também através de análise de Jurisprudência, em conjunto com entrevistas de atores envolvidos diretamente em lidar com os efeitos das decisões judiciais e mudanças nas políticas de assistência farmacêutica, esses estudos têm chegado à conclusão de que o Poder Judiciário, através dos Tribunais de Justiça, "por meio das milhares de decisões que toma anualmente efetivando o direito social à saúde pública é um importante ator político com poder de veto, capaz (...) de mudar o status quo legislativo" (Carvalho, 2013, pp. 134). Com isso em vista, Oliveira e Noronha (2011) rebatem o argumento de que o Judiciário cria privilégios ou descaracteriza um direito coletivo tornando-o individual, uma vez que o conjunto de suas decisões ajuda a moldar a política pública, criando impactos coletivos advindos das várias vitórias individuais.

Esses trabalhos também criticam o argumento muito presente na literatura do campo da Saúde Pública de que as cortes desconhecem ou ignoram as políticas públicas de saúde em suas decisões. Fanti (2009) argumenta, a partir do estudo do teor das decisões e argumentos mobilizados pelos juízes, que não seria esse o caso, que os tribunais reconheciam a existência de tais políticas, mas que estes não poderiam “abdicar de uma lógica estritamente voltada à interpretação e aplicação de direitos na tentativa de se ater a suas funções especificas determinadas pela separação de poderes" (pp. 88). Nesse mesmo sentido, Engelmann e Cunha Filho (2013), ao analisarem o teor

\footnotetext{
${ }^{19}$ Pode-se citar Atria (2004) e Calil (2012).
} 
de decisões judiciais de fornecimento de medicamentos no Tribunal de Justiça do Rio Grande do Sul, apontam que as questões orçamentárias e a organização das políticas públicas são reconhecidas pelos juízes ao proferirem suas decisões, que, no entanto, colocam o direito constitucional à saúde acima dessas questões.

O impacto no orçamento do Ministério da Saúde e nas secretarias de saúde também foi objeto de estudo, além dos efeitos (positivos e negativos) que as decisões judiciais têm em políticas públicas. Embora prevaleçam os argumentos de uma postura mais técnica e passiva, temos visto - embora ainda de forma incipiente - a manifestação e o debate interno ao Judiciário de temas de acesso à saúde, particularmente no âmbito do STF, no que diz respeito à concessão de medicamentos.

Wang (2013), ao analisar qualitativamente o teor de decisões do Supremo Tribunal Federal nos casos de direito à saúde, propõe que a jurisprudência do STF pode ser dividida em três fases: i) não aceitação pelo tribunal da condicionalidade do direito à saúde à existência de políticas públicas (1997-2006); ii) reconhecimento da necessidade de condicionar o direito à saúde à reserva do possível, mas sem estabelecer diretrizespadrão para as decisões (2007), e iii) estabelecimento de critérios para definir em quais casos a condicionalidade do direito à saúde deveria passar por judicial review (2009-).

A primeira fase se caracteriza pela interpretação de que a implementação integral do direito à saúde seria necessária à satisfação do princípio do mínimo existencial, correspondente ao conjunto de situações materiais indispensáveis à dignidade da pessoa humana e indissociável do direito à vida. Nesse sentido, o direito à saúde foi interpretado pela corte como um direito fundamental e individualmente exigível, e as limitações orçamentárias e das políticas públicas de saúde eram mencionadas nas decisões, apenas para reafirmar que tais constrições não poderiam limitar o direito à saúde. Nessa fase, o STF julgou 31 casos, decidindo sempre em favor do paciente.

A segunda fase é marcada pelo reconhecimento da necessidade de ponderação entre o direito à saúde, as restrições orçamentárias e as políticas públicas de saúde existentes. Em 2007, ao julgar a Suspensão de Segurança 3073, a Ministra Ellen Gracie, então presidente do Tribunal, firmou um entendimento diverso do consolidado pela corte até então, determinando a não concessão do medicamento pleiteado - que não se encontrava listado no rol de medicamentos do SUS. O cerne do argumento para essa decisão foi a definição do direito à saúde referente à efetivação de políticas públicas. $\mathrm{O}$ mesmo conjunto de argumentos foi utilizado pela Ministra para julgar o Agravo 
Regimental na Suspensão de Tutela Antecipada 91, também em 2007, e que teve grande repercussão junto às secretarias de saúde.

Em seu voto, a ministra reconheceu que o fornecimento gratuito de medicamentos de alto custo para pacientes com câncer pode representar uma violação ao artigo 196 da Constituição da República, uma vez que o dispositivo se refere "à efetivação de políticas públicas que alcancem a população como um todo, assegurandolhe acesso universal e igualitário, e não a situações individualizadas", dando interpretação diversa ao artigo 196 em relação àquela anteriormente firmada pelo STF. A ministra acatou o argumento do Estado de Alagoas, réu na ação, e reconheceu lesão a ordem pública, afirmando que a decisão do tribunal de origem afetaria o "já abalado sistema público de saúde". A Ministra ainda considerou em sua decisão que o Estado de Alagoas não estava se recusando a fornecer tratamento aos pacientes, pois estava garantindo tratamento dentro do que constava no SUS. Essas duas ações geraram efeito multiplicador, não da parte dos impetrantes, e sim da parte das secretarias de saúde, que começaram a ingressar na justiça com base na STA 91, com vistas a serem desobrigadas de fornecer medicamentos não constantes no rol do SUS que estavam obrigadas a fornecer por decisões judiciais anteriores.

Contrariamente ao que se podia esperar, as duas decisões da ministra Ellen Grecie não inauguraram um novo entendimento do Tribunal, a ser aplicado uniformemente a todos os casos. O que parecia inaugurar um ponto de inflexão na jurisprudência da corte não se concretizou nas decisões de casos subsequentes, que tornaram a se concentrar no irrestrito direito à saúde, sem considerar as políticas públicas existentes.

\subsection{Conclusão}

No marco constitucional de 1988, o Sistema Único de Saúde inovou ao postular o seu caráter universal, abolindo as distinções entre os cidadãos e forçando todo o sistema governamental a atuar de modo a realizar essa premissa universalizante do acesso à saúde. No entanto, a judicialização do direito à saúde, que se configurou em meio a processos judiciais majoritariamente individuais, reintroduziu no sistema público de saúde a fragmentação ao acesso e a diferentes níveis de cobertura combatida pelo movimento brasileiro sanitarista no momento da redemocratização em prol da noção universalista desse direito, concretizada no Sistema Único de Saúde. 
No que tange à estrutura do sistema de justiça, o fenômeno da judicialização deixou evidente a dificuldade em estabelecer uma coordenação vertical dentro do Judiciário. Mesmo que algumas inovações jurisprudenciais tenham surgido da mais alta corte do país, em teoria com potencial para orientar instâncias inferiores acerca da temática, a literatura dedicada à caracterização da judicialização do direito à saúde não observou mudança relevante no modo como as cortes de instâncias inferiores agem quando julgam ações dessa temática. Como vimos, com a independência decisória de que gozam os juízes, combinada com um uma ausência de controle externo, o tratamento judicial de casos inseridos no âmbito de uma política pública - que requereria um mínimo de coordenação e afinação de critérios - não parece ter alcançado êxito apenas a partir de inovações jurisprudenciais.

Na próxima seção, descreveremos algumas iniciativas que se deram fora dos processos judiciais e que foram colocadas em marcha para posicionar o Judiciário, enquanto instituição, em um novo patamar no que diz respeito à judicialização do direito à saúde. 


\section{AS RESPOSTAS INSTITUCIONAIS DO JUDICIÁRIO AO PROBLEMA DA JUDICIALIZAÇÃO DO DIREITO À SAÚDE}

Os trabalhos acerca da judicialização da saúde até aqui considerados se limitaram a caracterizar a judicialização do direito à saúde em suas três fases do ciclo da judicialização, conforme caracterizado por Oliveira (2005): i) analisar a politização da justiça nesse caso, através da análise do volume de ações que chegam ao Judiciário demandando questões relacionadas ao direito à saúde, ii) o julgamento de pedidos de liminar, e especialmente no caso do direito à saúde, os pedidos de suspensão antecipada de tutela - que colocamos nessa mesma fase do ciclo, por não se tratar de decisão definitiva, mas sim de decisão acerca de um pedido ele mesmo de caráter provisório e iii) a judicialização da política propriamente, que se caracterizaria pelo julgamento do mérito das ações, e o modo como as decisões interferiram no status quo vigente, seja ele orçamentário, seja ele organizacional da política pública de saúde. Um grupo de estudos recentes, cujos primeiros trabalhos iniciam-se em $2009^{20}$, têm se concentrado não em caracterizar as diferentes etapas do ciclo do fenômeno, mas em mostrar que tem havido uma maior politização desse tema no Judiciário, além da mobilização de grupos de interesse diretamente atingidos por decisões judiciais. $\mathrm{O}$ foco desse conjunto de trabalhos repousa nas respostas do Poder Judiciário, enquanto instituição, à judicialização do direito à saúde. Trabalha-se aqui com a distinção entre duas categorias de respostas do Judiciário: i) respostas advindas do exercício de função jurisdicional do Judiciário, caracterizadas como o acúmulo de sentenças (jurisprudência) proferidas por diferentes órgãos do Judiciário - dos juízos de $1^{\circ}$ grau aos Tribunais Superiores - ao decidirem um caso concreto dentro do modelo adversarial e ii) respostas institucionais do poder Judiciário, não diretamente resultantes da função jurisdicional típica desse poder, destinadas a resolver um caso concreto, mas que tem por natureza aumentar a capacidade institucional desse poder de lidar com essa questão, com vistas a promover um maior accountability judicial decisional ${ }^{21}$.

Os trabalhos de Oliveira e Noronha (2011) e de Wang (2013) demonstraram que, apesar de a grande maioria da jurisprudência relacionada às demandas de prestação de saúde ser uniformizada no sentido de concessão de medicamentos aos pacientes, o

\footnotetext{
${ }^{20}$ A literatura que analisa a judicialização do direito à saúde inaugura uma nova fase em 2009, acompanhando as respostas dadas pelo STF e CNJ, que serão analisadas a seguir.

${ }^{21}$ Tomio e Robl Filho (2013) definem accountability judicial decisional como" a possibilidade de requerer informações ou justificações dos magistrados pelas decisões judiciais, além de aplicar sanção por essas decisões" (p. 30)
} 
Poder Judiciário, enquanto instituição, tem recentemente tentado dar respostas às críticas que recebe ao tratamento que dá à questão e procurado rever a interpretação dominante desde os anos 1990 nesses tipos de casos. As respostas identificadas pelos autores partem tanto do órgão de cúpula do Judiciário, o Supremo Tribunal Federal, como do Conselho Nacional de Justiça. Ambos os órgãos compõem o Poder Judiciário, enquanto poder constitucionalizado, mas tem funções e natureza distintas dentro da organização desse poder constitucionalizado - o que leva às respostas dadas por cada um desses órgãos também terem funções e naturezas distintas

As respostas identificadas por Oliveira e Noronha (2011) e Wang (2013) são a realização da Audiência Pública no 4/2009 pelo STF e consequentes diretrizes expedidas por essa corte e pelo Conselho Nacional de Justiça (CNJ) que orientam as instâncias inferiores a buscar uma maior comunicação com os administradores públicos e a se informarem melhor a respeito das políticas de saúde e, em especial, da política de assistência farmacêutica, para dar decisões com maior embasamento técnico.

\subsection{Respostas do Supremo Tribunal Federal}

Entre os dias 27 de abril e 7 de maio de 2009, o então presidente do Supremo, Ministro Gilmar Mendes, organizou a Audiência Pública no 4/2009, que contou com diversos especialistas em direito sanitário, representantes do poder público e da sociedade civil, a fim de qualificar melhor o Tribunal para o julgamento de vários Recursos Extraordinários (RE) acerca da temática.

Após a Audiência Pública, o plenário do STF julgou em bloco vários REs interpostos pelo poder público contra decisões que determinaram a obrigatoriedade do fornecimento de medicamentos de alto custo e tratamentos não ofertados pelo Sistema Único de Saúde ${ }^{22}$. Nesses julgamentos, o tribunal reafirmou a jurisprudência da Corte, indeferindo os nove recursos. No entanto, o esforço argumentativo dos votos foi visivelmente maior, incorporando novos elementos à lógica de decisão. Em seu voto, o Ministro Gilmar Mendes faz uma longa digressão, afastando-se do caso concreto em análise para discorrer sobre todos os aspectos do direito à saúde e as conclusões resultantes da Audiência Pública. O ministro analisou pormenorizadamente as divergências doutrinárias na interpretação do artigo 196 da CF 88, e refletiu sobre a possibilidade de compatibilizar os princípios do mínimo existencial e da reserva do

${ }^{22}$ STA 175, STA 211, STA 278, SS 3724, SS 2944, SS 2361, SS 3345, SS 3355 e SL 47. 
possível. O Ministro destacou a existência de uma contraposição entre uma "proibição de excesso", quanto à concessão desenfreada de medidas judiciais, e uma "proibição de proteção insuficiente", a qual resultaria na ausência de atendimento necessário à manutenção da saúde (e vida) de quem necessitar. Postulou também que para as diferentes necessidades de cada cidadão há uma diferente resposta no Estado, e que isso caracterizaria uma prestação devida. Portanto, gastar mais recursos com uns do que com outros não violaria o princípio de igualdade, mas sim permitiria garantir o mínimo existencial previsto pela Constituição. $\mathrm{O}$ ministro reconheceu que as decisões judiciais muitas vezes entram em tensão com as políticas estabelecidas pelos governos para a área de saúde e vão além das possibilidades orçamentárias.

Argumentando estar baseado no resultado da Audiência Pública, o ministro elaborou em seu voto uma espécie de fluxograma que os membros do Poder Judiciário deveriam seguir ao decidirem questões acerca do fornecimento de prestações de saúde, estabelecendo diversos critérios, com a intenção de orientar as decisões futuras do STF no tocante à efetivação do direito à saúde. $\mathrm{O}$ ministro sugere que primeiro se considere se há "existência, ou não, de política estatal que abranja a prestação de saúde pleiteada pela parte. Se a prestação de saúde pleiteada não estiver entre as políticas do SUS, é imprescindível distinguir se a não prestação decorre de (1) uma omissão legislativa ou administrativa, (2) de uma decisão administrativa de não fornecê-la ou (3) de uma vedação legal a sua dispensação." ${ }^{23}$ Para cada uma das hipóteses, o ministro oferece maneiras de encaminhar a decisão, e o que deve ser levado em conta ao decidir se é razoável ou não conceder uma prestação de saúde não prevista em políticas do SUS, concluindo que o direito à saúde não restringe-se às políticas públicas do SUS, mas que a escolha deve ser, prioritariamente, pelo tratamento ofertado pelo SUS.

De maneira indireta, o ministro reconhece que o efeito multiplicador das ações dessa natureza ocorreu pelo fato de o Poder Judiciário garantir todas as prestações de saúde pleiteadas pelo mero reconhecimento do direito à saúde. Ele recomenda que haja instrução processual com ampla produção de provas para que "não ocorra a produção padronizada de iniciais, (...), que não contemplam as especificidades do caso concreto, impedindo que o julgador concilie a dimensão subjetiva (individual e coletiva) com a dimensão objetiva do direito à saúde.” O ministro dedica apenas 5 das 31 páginas de seu voto à análise do caso concreto da ação, negando provimento ao pedido da União, que

\footnotetext{
${ }^{23}$ STA 175
} 
estava baseado apenas numa alegação genérica de violação ao princípio da separação dos poderes e, recorrendo à jurisprudência da corte, entendeu o ministro que não havia configuração de lesão à ordem pública.

Apesar de o sentido da jurisprudência não ter mudado, a evolução no discurso dos ministros em seus votos, demonstrando preocupação com uma fundamentação mais intimamente ligada ao caso concreto, merece destaque. Nesse sentido, a principal crítica apontada pelos trabalhos do campo da Saúde Pública em relação à atuação do Judiciário, qual seja, que as cortes não tem levado em conta as políticas públicas de saúde ao se manifestar quase sempre a favor do paciente, independentemente de qual medicamento está sendo demandado e para qual condição clínica, parece ter sido absorvida pelo STF, que tem buscado qualificar melhor suas decisões e analisar de maneira mais detida as particularidades dos casos concretos.

\subsection{Respostas do CNJ}

Apesar de ter natureza e composição inteiramente diversa da do STF, a agenda do $\mathrm{CNJ}$ por vezes tem sobreposições àquelas consideradas importantes pelo presidente do STF, uma vez que este também ocupa a função de presidente do Conselho. Não por acaso, as consequências da Audiência Pública encabeçada pelo Ministro Gilmar Mendes, presidente do STF e do CNJ no biênio de 2008-2010, também tiveram ramificações no âmbito do Conselho, que publicou a Resolução n.31/2010. Aprovada pelo plenário do CNJ em março de 2010, tal resolução organizou as diretrizes em relação às demandas que envolvem o direito à saúde apontadas no voto do Ministro Gilmar Mendes no bloco de ações julgadas imediatamente após a Audiência Pública de 2009. Com a intenção de recomendar "a adoção de medidas visando a melhor subsidiar os magistrados e demais operadores do direito, para assegurar maior eficiência na solução de demandas judiciais envolvendo a assistência à saúde", conforme a ementa da resolução, a recomendação 31/2010 propõe algumas medidas para orientar a atuação do Poder Judiciário nas demandas de direito à saúde. A própria resolução estabelece que seu pano de fundo foi a audiência pública n. 4/2009, que levantou problemas como o alto impacto orçamentário para cumprimento das decisões e a falta de informações dos juízes acerca da política de assistência farmacêutica do SUS e a falta de participação dos gestores nos processos. $\mathrm{O} \mathrm{CNJ}$ recomendou, entre outras medidas, que os Tribunais de Justiça dos Estados e os Tribunais Regionais Federais: 
i) disponibilizassem apoio técnico de médicos e farmacêuticos para auxiliar os magistrados na avaliação de questões clínicas;

ii) instruíssem os magistrados a tomarem decisões baseadas em relatórios médicos e evidências clínicas e evitassem autorizar o fornecimento de medicamentos ainda não registrados pela Anivsa

iii) orientassem os magistrados a consultar os gestores de saúde antes de tomarem decisões, sempre que possível

iv) promovessem visitas dos magistrados aos conselhos municipais e estaduais de saúde e unidades de saúde.

Considerando essas duas respostas do Judiciário - a Audiência Pública 04/2009 organizada pelo STF e a Resolução 31/2010 d CNJ - os estudos de Oliveira e Noronha (2011) e Wang (2013) chegam a diferentes conclusões. Enquanto aqueles creditam a mudança de postura do STF a uma interação com membros do Poder Executivo e veem uma postura de cooperação entre os poderes acerca de como a efetivação do direito a saúde deve se dar, este tem uma visão mais negativa da atuação do Judiciário nos temas de saúde, argumentando que, ainda que esse poder tente seguir algumas diretrizes mais técnicas para embasar suas decisões, ele nunca terá capacidade institucional e legitimidade para tomar medidas técnica e politicamente acertadas nas questões de acesso a medicamentos e tratamentos de saúde. Wang propõe, então, que o Judiciário passe a deixar as decisões de fornecimento de medicamentos exclusivamente com os poderes Executivo e Legislativo e passe a atuar somente no controle do processo de avaliação e incorporação de novas tecnologias no SUS feitas pelos órgãos competentes.

\subsection{Conclusão}

Apesar de claramente assinalarem um ponto de inflexão na maneira como o Judiciário lida com a questão, as respostas do Judiciário identificadas até aqui pelos estudos de Wang e Oliveira e Noronha se concentram em diretrizes com a finalidade de orientar a atuação dos juízes das instâncias inferiores quando ações com demandas de saúde lhe foram apresentadas. Enquanto as diretrizes do STF, de caráter jurisdicional e materializadas no voto do ministro Gilmar Mendes, orientam para uma maneira de decidir que leve em conta as políticas públicas de saúde e o caso concreto, a recomendação do $\mathrm{CNJ}$, de natureza administrativa, deu um passo a mais, incentivando a capacitação dos juízes e o diálogo com os gestores de saúde, visando qualificar as 
decisões e legitimar o Poder Judiciário como ator capaz nessa temática. No entanto, a resolução do CNJ não aponta como as medidas recomendadas serão colocadas em prática, tampouco é obrigatória ou vinculante aos tribunais.

Ambas medidas analisadas por Oliveira e Noronha e Wang tiveram uma mesma intenção: reorientar a maneira como o Judiciário enxergava e lidava com a questão da judicialização da saúde até então. Apesar da recomendação de Wang (2013) para que o Judiciário deixasse as decisões de fornecimento de medicamentos exclusivamente aos poderes Executivo e Legislativo, ações permanecem continuamente chegando, através da Justiça Comum, às mãos de juízes de $1^{\circ}$ grau espalhados por todo o Brasil e exigem uma decisão, já que o Judiciário não pode se omitir se provocado. Levando-se em conta a extensão territorial do país, a diferença na velocidade e qualidade de informação que chega a cada juiz e, principalmente, a independência decisional de que gozam esses juízes, é improvável que uma única audiência pública comandada pelo STF em Brasília, assim como recomendações não vinculantes expedidas pelo CNJ sejam instrumentos suficientes para atingir os objetivos colocados. Descrevemos a evolução da judicialização da saúde e complexidade das ações que chegam ao Judiciário em sessões anteriores, mostrando que pedidos nesse sentido chegam ao Judiciário desde os anos 1990, e continuam sendo considerados procedentes na vastíssima maioria dos casos, apesar de algumas decisões consideradas icônicas no sentido oposto.

Se considerarmos instituições como "maneiras amplamente aceitas de se fazerem coisas" ${ }^{24}$, o que se procurou com a STA 175, a audiência pública n ${ }^{\circ}$ 04/2009 e com a resolução do CNJ 31/2010 foi uma mudança institucional, ou seja, uma transformação na "maneira de fazer as coisas". Essa definição ampla do que é uma instituição é particularmente útil para nossos propósitos, uma vez que não se pode obrigar juízes a decidirem de uma determinada maneira em casos de concessão de acesso à saúde: o estabelecimento de uma nova maneira de interpretação só é possível através do convencimento, e não de normas e regras que constranjam o comportamento dos juízes.

A constatação da literatura é que a maioria das sentenças sobre casos de judicialização leva em consideração fundamentos constitucionais - o artigo 196 - e não

\footnotetext{
${ }^{24}$ Conforme definição de ABERS e KEKC (2013), "we define institutions broadly as commonly accepted ways of doing things" (pag.03).
} 
fatos concretos de cada caso em questão, ou mesmo normas infra-constitucionais, como a Lei Orgânica da Saúde. Mesmo com recomendações que encorajem que esses fatores sejam levados em consideração advindas de documentos expedidos pelo próprio Judiciário, como fazer com que os juízes sigam essas recomendações? Em outras palavras, como fazer com que um vasto número de atores siga essas decisões principalmente em um contexto em que sanções não são aplicáveis ao comportamento dos magistrados, seguindo o princípio da independência judicial decisional?

Uma terceira resposta advinda do poder Judiciário, de caráter mais dinâmico, inclusivo e permanente, foi a instituição do Fórum Nacional do Poder Judiciário para monitoramento e resolução das demandas de assistência à saúde - Fórum da Saúde, mantido pelo Conselho Nacional de Justiça. Procuraremos argumentar que diferentemente das Audiências Públicas, que são um espaço de diálogo de curta duração e que dependem da vontade de um dos ministros em fazer seu chamamento, e das recomendações do $\mathrm{CNJ}$ - que apenas traçam diretrizes estanques, sem indicar como tais orientações serão colocadas em prática; o Fórum da Saúde, através de um longo processo de construção institucional, conseguiu avançar significativamente na mudança em como as coisas são feitas, isso é, na maneira como os juízes tem lidado com a judicialização da saúde. 


\section{O FÓRUM DA SAÚDE}

O Fórum da Saúde pode ser caracterizado como uma arena de diálogo permanente acerca de uma temática específica - a judicialização da saúde - criada por iniciativa do próprio Judiciário, e por ele comandada. O Fórum é um espaço institucionalizado dentro do $\mathrm{CNJ}$, no contexto dos programas específicos mantidos por esse órgão. Arantes (2015) denominou tais programas como "políticas públicas da justiça", apontando como singularidade de tais programas sua extensão para além dos mecanismos tradicionais de decisões do Judiciário, estabelecidos no campo da administração da Justiça.

Antes de entrarmos propriamente nos pormenores dessa instituição, é importante reafirmar que ela é fruto de um processo histórico que possibilitou seu surgimento. Em especial, dois antecedentes distintos possibilitaram o estabelecimento de um espaço como o Fórum da Saúde dentro do CNJ.

De um lado, o estabelecimento de um espaço institucionalizado como o Fórum só foi possível, pois já havia, dentro do próprio Judiciário, uma incipiente mentalidade que apontava para uma mudança institucional no que tangia a como os diversos órgãos desse poder lidavam com a temática da judicialização da saúde. Nesse sentido, a racionalidade que guiou a criação do Fórum foi a mesma que presidiu a convocação da Audiência Pública no 04/2009, e que também deu origem à recomendação 31/2010 do CNJ: discutir a judicialização do direito à Saúde com especialistas do campo da Saúde Pública e do Direito, gestores públicos e membros da sociedade civil, com vistas a obter informações técnicas, administrativas, científicas, econômicas e políticas para melhor instruir os processos que chegavam ao Judiciário, para qualificar e eventualmente diminuir a judicialização do acesso à saúde, conforme o Ministro Gilmar Mendes, à época presidente do Tribunal (e, portanto, também do Conselho), declarou na abertura da Audiência Pública. De acordo com o ministro, a necessidade de ouvir especialistas e a sociedade civil surgiu com o reconhecimento, por parte do Tribunal, de que a corte precisa do auxílio de diferentes partes para tomar decisões melhores, dado que a judicialização do direito à saúde gerava impacto significativo tanto na prestação jurisdicional - pelo excepcional volume que ações dessa temática atingiram - bem como na organização e alocação de orçamento do sistema público de saúde (BRASIL, 2009). No entanto, essa nova maneira de enxergar e lidar com a questão da judicialização da 
saúde parecia estar restrita aos órgãos de cúpula do Judiciário, com pouca ramificação nos outros órgãos e instâncias inferiores.

De outro lado, a iniciativa do Fórum da Saúde também só foi possível, pois havia um espaço institucional capaz de abrigá-lo dentro do Judiciário: o CNJ. Como afirmamos anteriormente, o caráter administrativo e não propriamente judicial do CNJ se mostrou uma grande vantagem nesse processo, uma vez que essa condição aproxima o Conselho dos órgãos típicos da administração pública, responsáveis pela implementação de políticas. Assim, a necessidade de dar continência aos desdobramentos da judicialização da saúde encontrou num órgão de administração da justiça o locus para o desenvolvimento de uma nova política pública, desta feita liderada pelo próprio Poder Judiciário. Em outras palavras, da ótica da administração da justiça e tendo em vista as metas institucionais do Conselho, o Fórum foi, em parte, estabelecido para gerir de algum modo os efeitos da judicialização, visto que abriga, por exemplo, um sistema eletrônico de monitoramento das ações e decisões judiciais que demandam prestações de saúde, formando uma base de dados centralizada, auxiliando no campo da administração da justiça e no planejamento estratégico dos tribunais. Por outro lado, a instituição de um fórum de caráter permanente para discussão específica da judicialização da saúde se espelhou em arenas semelhantes de discussão de temáticas específicas que já haviam sido instituídas, com maior ou menor sucesso, dentro do CNJ - notadamente o Fórum para Conflitos Fundiários. Ao final da Audiência Pública $\mathrm{n}^{\circ} 04 / 2009$, e percebendo que os resultados da mesma precisavam de uma discussão mais profunda e continuada, o ministro Gilmar Mendes, que à época presidia o STF e, portanto, também o CNJ, achou neste último um espaço institucional para dar perenidade maior à discussão. A ideia de levar os resultados da audiência pública para o CNJ já foi de certa forma criativa: a intenção de uma audiência pública chamada pelo STF, via de regra, é auxiliar o ministro - ou ministros - que a convoca a entender com maior profundidade, através da escuta de diversas partes interessadas e de especialistas, uma temática tida como mais complexa, com vistas a decidir um caso ou um grupo de casos. Deste modo, o curso natural de uma audiência pública é encerrado na decisão dos casos, pela via da sentença e jurisprudência. Encaminhar os resultados da AP 04/2009 para o CNJ já foi, portanto, algo incomum e representou um novo passo na judicialização da política nessa área.

As possibilidades, dentro do órgão, de como dar continuidade àquela discussão também eram múltiplas. Havia vários caminhos institucionais possíveis: apenas a edição 
de recomendações, prosseguir com o formato de audiências públicas, mas dessa vez encaminhadas dentro do CNJ, e não pela via do STF. A opção por estabelecer-se um fórum permanente de diálogo se deu em detrimento das outras alternativas, através da apropriação de um formato já utilizado pelo CNJ para tratar da questão de conflitos fundiários. De acordo com Rodrigo Rocha, servidor do CNJ que atua como secretário do Fórum da Saúde desde sua instituição, o Fórum de Conflitos Fundiários, instalado em 2009 mantido pelo CNJ, funcionava bem ainda em 2010, ano de instalação do Fórum da Saúde. Rocha relata que o fato de a questão dos conflitos fundiários, assim como a judicialização da saúde, envolver diversos atores de diferentes esferas, sendo também uma temática de grande complexidade, ajudou a tornar essa alternativa um bom modelo a ser seguido para o tema da saúde.

Curioso é o fato de que, apesar de ter servido de modelo ao Fórum da Saúde, o Fórum Nacional de Conflitos Fundiários foi posteriormente abandonado, enquanto o Fórum da Saúde continua funcionando há mais de sete anos e não dá sinais de que será abandonado em breve.

Por que o Fórum da Saúde ganhou tamanha relevância a ponto de continuar existindo, e sendo ativo em suas iniciativas, sete anos após sua instituição?

\subsection{Autoridade Prática: Uma teoria para explicar como instituições se tornam funcionais e relevantes.}

Abers e Keck (2013), em seu livro Practical Authority, propõem um enquadramento analítico para explicar como novos arranjos institucionais estabelecidos por meio de normas tornam-se operacionais na prática. Partindo de uma extensa pesquisa empírica sobre o porquê e como alguns comitês gestores de bacias hidrográficas no Brasil ganharam funcionalidade e representaram mudanças institucionais, ao passo que outros não, a conclusão a que as autoras chegam é que as instituições não se tornam instituições apenas pelas normas: elas precisam ser operacionalizadas.

Definindo instituições como "maneiras costumeiras de fazer as coisas" (ABERS e KECK, 2013, p. 03), as autoras procuram explicar como a construção de uma nova instituição - ou mudança institucional - se dá e como uma instituição ganha autoridade, definida como o tipo de poder que gera cumprimento de ações com base em legitimidade. $\mathrm{O}$ argumento principal das autoras é que instituições estatais ganham autoridade menos em função de suas atribuições formais e mais através de mecanismos 
relacionais. Para isso, desenvolvem o conceito de Autoridade Prática, definida como "o desenvolvimento de capacidades para resolver problemas e de ter o reconhecimento por outros atores-chave que permite a um ator (individual ou coletivo) influenciar comportamentos e tomar decisões que outros sigam" (pag. 06). Dois elementos são necessários para o desenvolvimento de Autoridade Prática: 1) o desenvolvimento de capacidades para resolver problemas e 2) o reconhecimento por outros.

Novas capacidades para resolver problemas podem ser de diversas ordens: atores podem adquirir novos conhecimentos técnicos, mobilizar recursos e relações para fazer as coisas de uma maneira não realizada por outros antes - como coordenar a ação entre vários outros atores e reorganizar o poder de decisão de uma agência para outra. $\mathrm{O}$ reconhecimento, por outro lado, vem da capacidade de resolver problemas demonstrada por uma instituição. Sendo a autoridade prática, como definida pelas autoras, a capacidade de influenciar comportamentos, ela só existe enquanto tal se os atores que precisam cumprir com as decisões reconhecerem que tal autoridade existe.

Após definirem que uma nova instituição vem a tornar-se funcional quando ganha autoridade prática, as autoras se dedicam a investigar como a autoridade prática é construída. 
Figura 2 - A construção da autoridade prática, segundo Abers e Keck (2013)

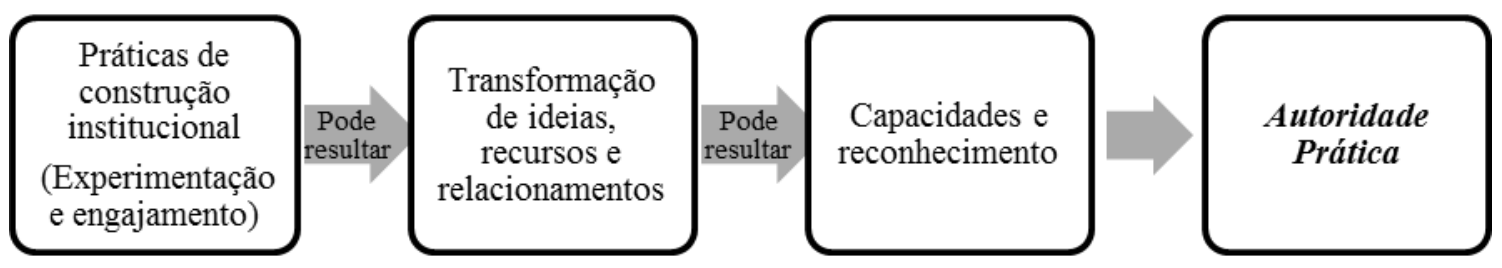

Fonte: Abers e Keck (2013). Reprodução da Figura 1.1 A construção da Autoridade Prática (p. 19)

A figura 2 busca esquematizar as etapas necessárias para a constituição da autoridade prática por uma instituição. Não se trata, contudo, de uma lógica linear e causal: etapas anteriores, quando presentes, podem resultar em constituição de autoridade prática, mas não necessariamente levam a esse resultado. No entanto, as autoras encontram que naqueles comitês em que uma autoridade prática foi observada, as etapas anteriores que culminaram nesse resultado foram as exemplificadas no esquema.

De maneira simplificada, a busca por transformar a maneira como as coisas são feitas (ou seja, práticas de mudança institucional) parte de duas estratégias muito bem discerníveis: a experimentação concreta com novas maneiras de resolver problemas e o engajamento de atores-chave para a tranformação institucional. As autoras estabelecem esse processo em meio à dicotomia entre agência e estrutura por vezes encontrada na literatura que lida com mudança institucional, isso é, não colocam uma ênfase maior nem na agência, nem na estrutura para explicar mudança institucional, mas buscam explicar a transformação da estrutura através do uso criativo pelos atores dessa mesma estrutura. Em outras palavras, a agência criativa dos atores seria exercida por meio de experimentação com novos usos das instituições existentes e novos jeitos de resolver problemas dentro dessas estruturas, mudando assim as mesmas estruturas que serviram de base para a experimentação, em um processo contínuo e de retro-alimentação de intervenção prática.

A dimensão da intervenção prática no mundo é chave no pensamento das autoras, pois é ela, em última análise, que fará a diferença quanto a boas ideias e leis serem capazes de gerar mudança institucional ou não. A tradução da criatividade e da agência criativa para uma agência transformativa, portanto, se daria justamente através 
da mobilização de recursos e relacionamentos para a experimentação concreta e engajamento dos atores.

A experimentação e o engajamento de atores podem levar à reconfiguração de relações de poder, de maneiras de interpretar o mundo e de usar os recursos existentes de novas formas. Com isso, novas capacidades para resolver problemas poderiam aparecer, juntamente com o reconhecimento dessas novas capacidades e proposições de resolução de problemas por atores-chave envolvidos, o que, por fim, resultaria na autoridade prática de uma nova instituição, ou seja, na capacidade de propor novas maneiras de se resolver problemas, que são reconhecidas e seguidas por outros atores.

Uma camada de complexidade adicional é introduzida no framework analítico das autoras quando elas analisam a construção de autoridade prática em "ambientes emaranhados" (entagled environments, no original), com vistas a entender se há algum elemento adicional para o sucesso da construção de autoridade prática sob essas condições.

Ambientes emaranhados acontecem quando o processo decisório e de implementação de uma política pública exige altos níveis de coordenação entre diversos atores e em esferas diferentes, especialmente em estruturas federativas, em que há descentralização de tomada de decisão e implementação das decisões. Como já exposto anteriormente, a judicialização do acesso à saúde, enquanto fenômeno, mobiliza dois grupos de atores e processos, cada um deles já operando em arranjos organizacionais bastante complexos: processos e atores envolvidos com política pública de saúde; e os processos e atores do Judiciário, além claro de outros operadores do direito (como advogados, Defensoria Pública, Ministério Público). Tanto a política pública de saúde quanto o Poder Judiciário são estruturados de forma descentralizada no Brasil, ainda que de forma hierarquizada - e uma mudança institucional em qualquer um desses dois pólos requer alto grau de coordenação entre os atores. A judicialização do acesso à saúde, que se dá pela ativação intercalada desses dois polos, ganha assim um grau de complexidade ainda maior.

Para caracterizar o ambiente emaranhado no qual a judicialização do acesso à saúde se desenrola, é útil pensar na noção de "legalization" de uma política pública formulada por Gauri \& Brinks (2008). Para esses autores, quando ocorrre a judicialização de uma política pública, põe-se em marcha uma ação pendular entre dois pólos - o Judiciário e a instância burocrática-governamental alvo da ação - seguindo as seguintes etapas, em um ciclo contínuo: i) ingresso com a ação no tribunal; ii) decisão 
judicial; iii) resposta à decisão, podendo ser burocrática, política ou de uma parte privada e iv) novos processos derivados da judicialização inicial (follow-up litigation). Os autores denominam de legalization o cumprimento dessas quatro etapas, formando um looping.

A argumentação de fundo dos autores é que a legalization de uma dada política pública torna o sistema judicial - ou seja, o conjunto das instituições de justiça e operadores do Direito - um "ator relevante, e a linguagem e categorias do Direito se tornam conceitos relevantes, no desenho e implementação da política pública" (Gauri \& Brinks, 2008, pp 4). Assim, a alteração na maneira como a política pública é interpretada, implementada e judicializada requeriria ações coordenadas nos dois pólos ativos no processo de legalization, em substituição à dinâmica pendular do processo.

Aplicado à política pública de saúde no caso brasileiro, tal processo tem, em uma ponta, o gestor público - que é, ao mesmo tempo, autor de políticas públicas de saúde e alvo de ações judiciais, que impactam a execução de tais políticas. Na outra ponta, está o juiz, que através de decisões acerca de processos judiciais que questionam o direito à saúde e as políticas públicas existentes, toma medidas que impactam nestas, mesmo não sendo gestor público. A interação entre os atores é constante, mas nenhum deles tem domínio completo sobre o processo de legalization. A figura 3 é uma tentativa de ilustrar esse processo.

\section{Figura 3 - O processo de legalization}

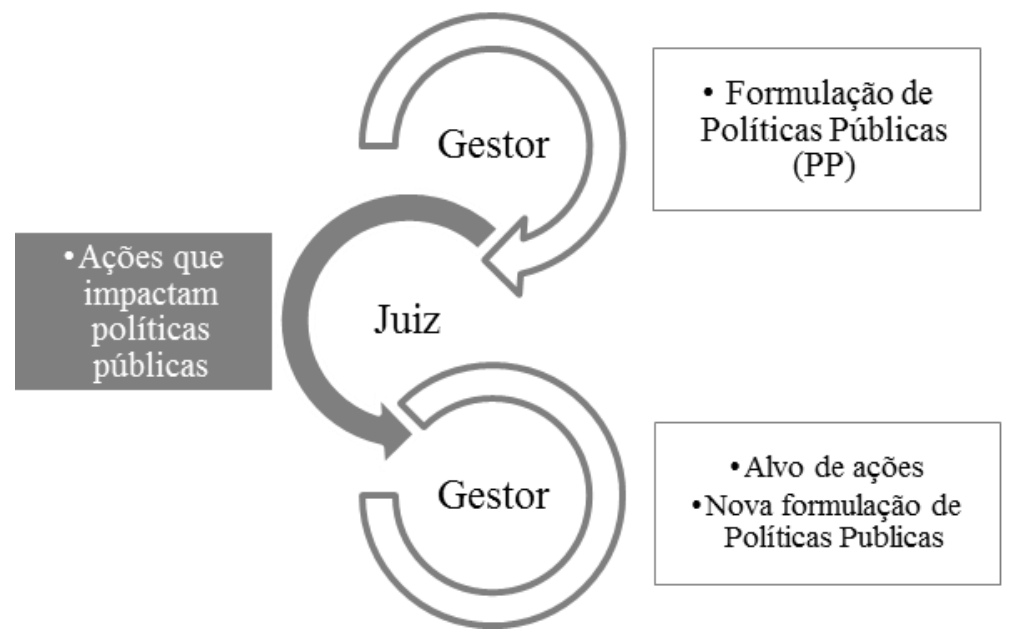

Fonte: Elaborado pela autora 
O processo de legalization ilustra bem o ambiente emaranhado no qual se localiza e desenrola a judicialização do acesso à saúde, por demonstrar o nível de ação concertada necessária intra e inter polos para uma mudança institucional.

Nesses casos, a construção bem-sucedida de autoridade prática exige, também, que as práticas de construção institucional se deem em um ambiente estrategicamente localizado, em que experimentos concretos com novas maneiras de se fazer as coisas e de mobilizar recursos e engajamento de atores sejam possíveis sem enfrentamento de grandes oposições, isso por que são ambientes em que há muitos pontos de veto e muita diversidade de interpretações, em que enfrentar uma oposição muito forte logo no começo pode acabar com o processo de experimentação antes que ele ganhe importância. Abers e Keck (2013) identificam duas rotas para "navegar o emaranhamento", geralmente tomadas de forma simultânea: uma é achar um espaço estratégico localizado na intersecção de redes de poderes em oposição para tentar experimentações em pequena escala, que geram novas capacidades e reconhecimento dos atores-chave de forma crescente; a outra é achar formas criativas de se engajar com arenas decisórias já existentes e aumentar a escala das experimentações a partir delas (Abers \& Keck, 2013, pag. 23).

Como vimos até aqui, a mudança institucional - entendida como novas maneiras comumente aceitas de se fazer as coisas - não se traduz em realidade apenas pela sua regulamentação pela via normativa. Uma nova maneira comumente aceita de lidar com a judicialização da saúde, portanto, depende, por um lado, da construção de novas capacidades para se resolver problemas e, por outro, de reconhecimento por parte dos atores-chave envolvidos de que existem novas maneiras de se resolver problemas que não as amplamente aceitas e já praticadas.

Na próxima seção, buscaremos argumentar que o Fórum da Saúde do CNJ, de forma muito particular, alcançou a autoridade prática necessária para iniciar uma mudança institucional, diferentemente do que ocorreu com as outras respostas institucionais dadas pelo Judiciário e Executivo até então. 


\subsection{O Fórum da Saúde e a Construção de Autoridade Prática}

Procuraremos verificar e explicar o processo de construção de autoridade prática do Fórum da Saúde, por meio da análise de como se deram as práticas de construção institucional colocadas em marcha pelos atores que compuseram e compõem o Fórum da Saúde, que contribuíram para a criação de novas capacidades e reconhecimento dessa instituição e consequente mudança institucional no que tange à judicialização da saúde, com especial foco na judicialização da saúde pública ${ }^{25}$.

Com esse objetivo, a pesquisa empírica seguiu duas estratégias distintas, porém complementares, para entender quais foram as experimentações colocadas em prática pelo Fórum e de que forma se deu o engajamento de atores-chave: 1) análise documental das normas que organizam o funcionamento dessa instituição, bem como as normas por ela produzidas e 2) entrevistas semi-estruturadas ${ }^{26}$ com 10 atores-chave que participaram/participam da construção institucional do Fórum da Saúde. Foram entrevistados atores que estiveram envolvidos em diversos momentos do Fórum, desde sua instauração em 2010 até membros atuantes ao final do ano de 2016, representantes de diversas agências e órgãos representados no Fórum ao longo desses 7 anos (de 2010 a 2016): 4 juízes ou desembargadores, um representante da defensoria pública, um representante do Ministério Público, uma representante do Ministério da Saúde, uma representante do CONASS, uma representante do CONASEMS, além de um funcionário do $\mathrm{CNJ}$, bacharel em direito, o qual atua como secretário dos conselheiros coordenadores do Fórum e que, apesar de não compor formalmente o Fórum, acompanhou sua trajetória desde 2010 e esteve presente em grande parte das reuniões do Comitê Executivo Nacional.

As entrevistas foram analisadas tanto da perspectiva individual, levando-se em conta a trajetória do entrevistado e a que instituição ele representava, como de forma coletiva, a partir dos pontos de consonância entre os discursos.

$$
* * *
$$

\footnotetext{
${ }^{25}$ Existe uma crescente judicialização da saúde suplementar, de natureza distinta da judicialização da saúde pública. O Fórum da Saúde também começou a lidar com essa judicialização, conforme esse tipo de processo começou a ganhar volume. No entanto, essa questão não está dentro do escopo dessa pesquisa.

${ }^{26}$ Uma cópia do roteiro de entrevista utilizado pode ser encontrada no apêndice dessa dissertação.
} 


\section{Início: Primeira composição e primeiras experimentações}

A institucionalização do Fórum foi, juntamente com um conjunto de resoluções expedidas pelo CNJ, resultado da Audiência Pública 04/2009, diante da constatação liderada pelo ministro Gilmar Mendes acerca da necessidade de continuidade daquela discussão para se reduzir e qualificar a judicialização do acesso à saúde (BRASIL, 2009). Como exploramos, a extrapolação da discussão de uma audiência pública chamada pelo STF para além de sua função fundamental - auxiliar os magistrados a exercerem a função jurisdicional, ou seja, decidir casos - já foi, em si, um exercício de agência criativa. A tranformação da parte ideacional em uma parte prática dependeu da mobilização de recursos e relacionamentos. O ministro Gilmar Mendes mobilizou sua influência na agenda do CNJ, por ocupar a presidência tanto do STF quanto do Conselho naquela ocasião, para migrar a discussão para esse lócus institucional. A justificativa dada para o CNJ se ocupar dessa temática, sendo ele um orgão de administração da justiça de natureza não jurisdicional, repousou na argumentação de que o grande volume de ações com pedidos de fornecimento de prestação de saúde que chegavam ao Judiciário todos os meses tinha grande impacto na eficiência e celeridade da prestação jurisdicional - este sim um tema do qual se ocupa o $\mathrm{CNJ}$, de acordo com seus objetivos institucionais.

Uma vez acolhida dentro do $\mathrm{CNJ}$, era necessário definir a forma como a discussão ganharia continuidade. Um grupo de trabalho foi estabelecido dentro do CNJ, a pedido do ministro Gilmar Mendes, para decidir como encaminhar a questão. Apesar de aventada a ideia de se continuar com o modelo de audiências públicas, dessa vez sob o chamamento do Conselho, a ideia de reaproveitar um modelo de um programa que já funcionava sob coordenação do CNJ, o do Fórum Nacional de Conflitos Fundiários, para abrigar a discussão dessa temática foi escolhida, muito em razão do fato de que o Fórum de Conflitos Fundiários tinha boa aceitação e avaliação positiva dentro dos prórios conselheiros. Os resultados desse grupo de trabalho geraram a resolução 31/2010 - já analisada anteriormente - e a criação do Fórum da Saúde.

A instalação do Fórum se deu por dois principais atos do $\mathrm{CNJ}$. O primeiro deles foi a Resolução n ${ }^{\text {o }}$ 107/2010 do CNJ, que instituiu o Fórum, conferindo-lhe atribuições como elaborar estudos e propor medidas concretas e normativas para o aperfeiçoamento de procedimentos, o reforço à efetividade dos processos judiciais e à prevenção de novos conflitos - a espelho do Fórum de Conflitos Fundiários. 
A Resolução n 107/2010 também previu como o Fórum de Saúde deveria ser estruturado hierarquicamente e como se daria sua composião. Optou-se por estruturar o o Fórum em comitês executivos, para coordenar e executar ações de natureza específica, devendo apresentar relatório sobre suas atividades semestralmente ao plenário do CNJ. Nessa primeira resolução, a composição prevista do Fórum contaria com magistrados atuantes em unidades jurisdicionais, especializadas ou não, que tratem de temas relacionados ao objeto de sua atuação, podendo contar com o auxílio de autoridades e especialistas com atuação nas áreas correlatas, especialmente do Conselho Nacional do Ministério Público, do Ministério Público Federal, dos Estados e do Distrito Federal, das Defensorias Públicas, da Ordem dos Advogados do Brasil, de universidades e outras instituições de pesquisa.

Sendo o Fórum de Saúde uma iniciativa do Poder Judiciário, e cuja instalação dentro do CNJ se justificou pela busca de melhor eficiencia na prestação jurisdicional, a primeira composição previa que seus membros seriam apenas magistrados, com possibilidade de contar com outros operadores do direito. A possibilidade de membros externos ao mundo do direito e de magistrados existia, mas colocada vagamente, na forma de "auxílio" - ou seja, não membros permanentes - de "especialistas com atuação nas áreas correlatas".

Após a publicação da Resolução 107, foi editada a Portaria nº 91/2010, que regulamentou o Fórum, ou seja, determinou os detalhes do que foi, de forma mais geral, estabelecido pela Resolução 107/2010. A portaria 91/2010 instituiu o Comitê Organizador do Fórum da Saúde, com competência para instalar o Fórum e conduzir suas atividades. O Comitê Organizador é uma espécie de burocracia dotada de capacidade gerencial, de natureza permanente, cujas funções incluem, mas não se limitam, a fazer cumprir o programa de trabalho do Fórum; organizar encontros nacionais de membros do Poder Judiciário, com ou sem a participação de outros segmentos do poder público, da sociedade civil e de comunidades interessadas, para a discussão de temas relacionados às suas atividades e para a proposição de medidas que contribuam para a solução de questões relacionadas às demandas de assistência à saúde. O Comitê Organizador do Fórum executa suas funções com verbas destinadas aos programas permanentes do $\mathrm{CNJ}$, que também destaca funcionários de seus quadros para atuar no secretariado e organização das atividades do Fórum. O Comitê Organizador, também referido como Comitê Executivo Nacional, ficaria sob coordenação da Comissão Permanente de Relacionamento Institucional e Comunicação do CNJ, 
responsável por supervisionar os trabalhos do Comitê Organizador. A resolução também estabelecia, de forma vaga, que no âmbito do Fórum Nacional seriam instituídos comitês executivos, sob a coordenação de magistrados indicados pela presidência e/ou corregedoria do CNJ. Não há na normativa qualquer especificidade quanto ao número de comitês executivos ou a como se dariam suas estruturações (se por temática ou escopo regional de atuação, por exemplo), nem como seria a sua composição. Mais tarde, esses comitês executivos se tornariam comitês estaduais, mas sem nenhuma resolução específica que determinasse isso ou detalhasse seu escopo de ação ou objetivos específicos. Apenas suas composições, cujas instituições representadas e número de membros variarem de comitê para comitê, são publicadas em forma de resolução do $\mathrm{CNJ}$.

$\mathrm{Na}$ ausência de regulamentação com definição de funções específicas para essas diferentes instâncias, o que a experiência prática configurou foi uma organização do Fórum da Saúde estruturada de forma descentralizada, sendo o Comitê Executivo Nacional responsável por elaborar diretrizes e planos de ação, enquanto os comitês estaduais - onde implantados - são responsáveis pela execução dos planos de ação e implementação das diretrizes, de acordo com as realidades locais e recursos capazes de serem mobilizados pelos coordenadores locais. A formalização de uma estrutura que havia surgido de experimentações práticas e já funcionava em alguns estados - os comitês estaduais de saúde - só veio em 2016, com a Resolução 238/2016. Das entrevistas realizadas com os coordenadores de comitês estaduais - Clênio Schulze (RS), Renato Dresch (MG) e Milene de Carvalho Henriques (TO), além de membro do Comitê Nacional com atuação no comitê executivo estadual de seu estado (PR) - fica claro que os comitês estaduais não tiveram um papel definido ou objetivo específico quando surgiram, antes da Resolução 238/2016. Cada comitê estadual se organizou de uma maneira, conforme os recursos disponíveis em cada localidade, e as ações dependeram, em grande parte, do que os entrevistados chamaram de "pró-atividade do coordenador". Das quatro experiências locais a que tivemos acesso por meio das entrevistas, fica como ponto comum a capacidade dos coordenadores de engajar diferentes atores para compor os comitês - sendo pelo menos um representante da gestão na secretaria da saúde presente como titular - e no uso criativo de instâncias e recursos já existentes para implementar e divulgar as ações, resultados e diretrizes do Comitê Nacional. Como exemplo, o comitê estadual de Tocantins começou uma experiência-piloto no município de Araguaína em 2015 que procurava dar soluções 
administrativas para os processos que chegavam. Para isso, engajou atores do ministério público e da defensoria e juízes, para que se utilizassem dos Núcleos de Apoio Técnico instaurados no estado (os chamados NATs, que analisaremos mais profundamente na próxima seção) para esclarecimentos sobre quadro clínico do paciente e de quem era a competência federativa para fornecer o que estava sendo demandado na ação, além de resolver pré processualmente as ações que demandavam prestações de saúde já oferecidas pelo SUS, direcionando tais processos para a ouvidoria do SUS no município, que disponibilizou uma área na superintendência da saúde da secretaria apenas para avaliar e dar resolutividade às questões, além de manter uma interlocução com o NAT estadual.

A Resolução 238/2016 em muito se baseou nas experiências práticas bem sucedidas dos comitês estaduais "precursores": colocando a criação desses comitês a cargo dos Tribunais de Justiça e os Tribunais Regionais Federais e estabelecendo uma composição mínima ${ }^{27}$. Em muito refletindo as composições dos comitês estaduais já existentes, o ato normativo também instituiu um escopo de atuação mínimo desses comitês, novamente refletindo experiências bem sucedidas dos comitês estaduais já constituídos: auxiliar os tribunais na criação dos Núcleos de Apoio Técnico - NATs.

Em relação ao Comitê Executivo Nacional do Fórum, sua primeira composição, em 2010, contava com membros do poder Judiciário - representados por desembargadores, juízes da vara da fazenda pública e servidores especialistas em direito sanitário - além de especialistas em direito sanitário externos à magistratura. No entanto, não havia representantes de qualquer instância do SUS, ou especialistas da área da saúde pública. Pouco tempo depois do estabelecimento do Fórum, o Ministério da Saúde (MS) requereu ao presidente do CNJ que um representante do Ministério fosse nomeado e passasse a atuar naquela nova arena institucional que acabara de ser criada requerimento esse que foi atendido. Dessa forma, o MS passou a ter uma representante no Fórum da Saúde ${ }^{28}$. É importante reconhecer que o pedido do Ministério da Saúde

\footnotetext{
${ }^{27}$ Representação mínima de Magistrados de Primeiro ou Segundo Grau, Estadual e Federal, gestores da área da saúde (federal, estadual e municipal), e demais participantes do Sistema de Saúde (ANVISA, ANS, CONITEC, quando possível) e de Justiça (Ministério Público Federal e Estadual, Defensoria Pública, Advogados Públicos e um Advogado representante da Seccional da Ordem dos Advogados do Brasil do respectivo Estado), bem como integrante do conselho estadual de saúde que represente os usuários do sistema público de saúde, e um representante dos usuário do sistema suplementar de saúde que deverá ser indicado pela Secretaria Nacional de Defesa do Consumidor por intermédio dos Procons de cada estado.

${ }^{28}$ O Ministério da Saúde é representado desde 2010 pela mesma servidora.
} 
constituiu em si mesmo uma demonstração de como esse programa começava a ser reconhecido como relevante também por atores não judiciais.

Em nenhum dos documentos de criação do Fórum fica estabelecida uma agenda de trabalho ou práticas concretas a serem tomadas por qualquer instância que compõe o Fórum. Ficou estabelecido apenas o espaço institucional para se discutir uma temática, de forma ampla e com objetivos principiológicos. A evolução da discussão, a forma que ela tomaria, e o avanço na agenda estavam, portanto, abertos (e incertos).

Após estabelecido, o Fórum da Saúde começou a gestar um conjunto de iniciativas focadas em promover o diálogo entre o sistema judicial e o sistema de saúde.

As primeiras iniciativas do Fórum foram as reuniões dos comitês, tanto nacional quanto estaduais, em que os membros se reuniam para discutir a judicialização do acesso à saúde e seus impactos. Por ter composição eclética de membros e liberdade de pauta para discussões mais gerais, isso é, não circunscrita a ações específicas, essas reuniões tiveram como principal função proporcionar um diálogo institucional entre os atores acerca de dificuldades e entendimentos gerais sobre direito à saúde e execução das políticas públicas de saúde. Essa aproximação entre os atores que compõem o sistema judicial (além dos magistrados, promotores de justiça, procuradores e membros da defensoria) e o de saúde, para além da interação via processos judiciais, teve o importante papel de reduzir o isolamento decisionista desses dois polos ao colocá-los em diálogo num ambiente em que esses atores não se encontravam forçosamente em lados opostos.

Nesse mesmo sentido de proporcionar espaços para o diálogo entre atores, o Fórum também organizou eventos para o debate do tema, o Encontro Nacional do Fórum da Saúde, realizado em 2010 e novamente repetido em 2011. Essa primeira iniciativa mais ampla, para além das reuniões dos comitês, destinada a avançar em formas de discutir a judicialização do acesso à saúde, deu-se muito baseada em formas já conhecidas de organizar discussões e debates pelo Judiciário: a reunião de diversos atores envolvidos no tema para a discussão, em forma de falas pré-definidas e posterior debate, durante poucos dias. $\mathrm{O}$ formato em muito lembra congressos realizados pelo Judiciário e, de certa forma, Audiências Públicas. A experimentação com as iniciativas do Fórum começou, portanto, a partir de um formato e uma cultura já bem familiares dentro do próprio Judiciário. Esses encontros tinham um caráter sobretudo organizador do debate da judicialização do acesso à saúde para os membros da magistratura, sem 
deixar um legado documental posterior diretamente relacionado ao seu acontecimento. Por fim, nessa fase inicial o CNJ também recomendou a proposta de inclusão do direito sanitário como disciplina obrigatória em concursos públicos de ingresso na magistratura e nos cursos de formação e aperfeiçoamento.

\section{Ganhando reconhecimento: engajando novos atores e novas experimentações}

Em sua recomposição, em março de 2014, o Comitê Executivo Nacional passou a contar com integrantes também do poder Executivo, como representantes do Ministério da Saúde, ANVISA, ANS, do Conselho Nacional de Secretarias da Saúde (CONASS) e do Conselho Nacional de Secretarias Municipais de Saúde (CONASEMS), seguindo o que já acontecia nos comitês executivos estaduais, cujas composições eram mistas desde suas criações, em 2010. A recomendação era que tanto os comitês estaduais quanto o Comitê Executivo Nacional contemplassem membros do sistema de justiça e do sistema de saúde, de modo que o diálogo entre estes atores diretamente relacionados com os efeitos da judicialização da saúde pudesse se dar. Porém, diferentemente do que aconteceu nos quatro comitês estaduais cujos coordenadores ou participantes foram entrevistados (RS, PR, MG e TO), em que ficou à cargo dos coordenadores o convite aos membros que não pertenciam ao sistema de justiça, em especial representantes da secretaria de saúde ou da gestão do Sistema Único de Saúde, a inclusão de novos atores foi feita "de fora para dentro", ou seja, não foi um convite do Fórum, mas uma solicitação de participação ao Fórum. As razões para isso vieram dos espaços de diálogo de curta duração que o Comitê Executivo Nacional organizou e da relevância que esses espaços tomaram aos olhos dos atores que viriam a pedir sua inclusão no lócus de discussão permanente, isso é, o Fórum.

Em 2014, também os Encontros tomaram um novo formato e foram rebatizados de Jornadas do Direito à Saúde. O pedido de maior pluralização em relação aos Encontros veio de membros externos à magistratura, em especial por um representante da Defensoria Pública e da gestão do SUS. Idealizado pela conselheira à frente da supervisão do comitê Executivo Nacional do Fórum à época, Deborah Ciocci, especialista em direito à saúde, as Jornadas tiveram como maior distinção em relação aos Encontros a pluralização dos participantes e o objetivo de elaboração de enunciados como resultado concreto dos debates. De acordo com o regulamento das inscrições para as Jornadas, eram seus objetivos: 1) produzir, aprovar, revisar, publicar e divulgar 
enunciados interpretativos sobre o direito à saúde; 2) identificar e compilar interpretações já consolidadas sobre a matéria, e 3) auxiliar, de forma pedagógica, a comunidade jurídica na interpretação de questões não pacificadas no âmbito doutrinário e jurisprudencial.

Fizeram parte desses debates, em suas duas edições, representantes do Ministério Público, Defensoria Pública, Juízes de Vara de Fazenda Pública e Cíveis, advogados, médicos do SUS, gestores do SUS, assessorias jurídicas das Secretarias de Saúde, membros do COSEMS - Conselho das Secretarias Municipais de Saúde, membros do CONASS, além de especialistas em direito sanitário e saúde pública.

Foram dois os maiores desdobramentos dos Encontros e das Jornadas.

O primeiro, de cunho normativo, foi a elaboração de enunciados, debatidos ao longo do evento entre os atores e construídos coletivamente. Os enunciados são divididos por temáticas - saúde pública, saúde suplementar e bio-direito - e refletem entendimentos comuns entre os participantes. A elaboração dos enunciados é uma iniciativa pré-processo, mas que visou, de algum modo, também uniformizar entendimentos dentro do próprio Judiciário acerca dos temas-alvo dos enunciados. Tais enunciados, no entanto, tais como o resultado documental da AP 04/2009 - ou seja, o registro que se fez no processo julgado no STF através do voto do Ministro Gilmar Mendes - e da recomendação 31/2010 do CNJ, eram normativos.

Antes da realização das Jornadas, que tiveram duração de 2 dias em ambas edições, foi feita uma convocatória para a apresentação de propostas de enunciados, a serem debatidas durante o evento e aprovadas por uma Comissão especial, como resultado dos debates. A intenção dos enunciados era que eles fossem instrumentos de auxílio aos juízes em decisões de matérias relacionadas ao direito à saúde. O fácil acesso a esses enunciados - que foram e permanecem disponíveis no site do Fórum da Saúde - e a elaboração conjunta entre atores interessados, com consequente aprovação por uma comissão científica, garantiria (ao menos em tese) uma informação baseada em evidências e conhecimento multidisciplinar, além de representar uma interpretação pacificada entre especialistas em direito sanitário com a escuta de gestores do SUS e especialistas em saúde pública.

Na visão de Deborah Ciocci, que idealizou esse formato e que é, ela mesma, uma jurista especialista em direito à saúde, uma das grandes dificuldades dos juízes que decidiam as ações com essa temática era a falta de conhecimento especializado e, diante da jurisprudência e da pressão de decidir sobre a vida de um indivíduo, se 
fundamentavam no direito à saúde e sua ligação com o princípio da dignidade humana sem considerar outros fatores. A esse respeito, Alethele Santos, que representa o CONASS no Comitê Executivo Nacional do Fórum da Saúde, esclareceu em entrevista que para a grande maioria dos juízes, o debate se faz no processo, ou seja, nas peças processuais. De acordo com ela, o advogado público não fazia o debate dos gestores públicos e nem da estruturação do SUS. Citando uma pesquisa da Fiocruz, Alethele aponta uma deficiência nas defesas em processos que buscam o fornecimento de alguma prestação de saúde, o que dificulta inovações nas sentenças dadas.

A ideia dos enunciados, portanto, foi sistematizar de forma curta e clara (os enunciados não passam de 10 linhas), alguns aspectos de contextualização do sistema público de saúde e recomendações de decisão pelo Poder Judiciário em casos específicos. As propostas de enunciados foram enviadas previamente às Jornadas, a partir de uma convocatória aberta e divulgada pelo Fórum. Qualquer pessoa estava habilitada a enviar sua sugestão de enunciado, para ser debatido, analisado e, eventualmente, emendado durante as Jornadas, para posteriormente serem ou não aprovados. Uma análise dos enunciados selecionados para discussão para a segunda Jornada $^{29}$ mostra a pluralidade de proponentes: procuradores, advogados, professores universitários de direito e de saúde pública, especialistas em regulamentação de saúde suplementar, defensores públicos, representantes de associações de pacientes, profissionais da saúde pública, analistas judiciários de TJs, médicos, representantes de associações da indústria farmacêutica, desembargadores, representantes dos comitês estaduais do Fórum (que enviaram os enunciados nessa condição, e não na condição de sua atuação profissional) e, finalmente, gestores públicos.

Foram 93 os enunciados selecionados, dos quais 21 foram aprovados em uma das três categorias possíveis: saúde suplementar, saúde pública e bio-direito. Na primeira Jornada, 45 foram aprovados no total, também distribuídos em uma das 3 categorias possíveis. Do total de enunciados aprovados ${ }^{30}$ nas duas Jornadas realizadas até 2016- 68 - 34 eram de Saúde Pública, ou seja, 50\% do total.

Do ponto de vista substancial, os 19 enunciados de Saúde Pública aprovados na I Jornada diziam respeito à estrutura e normativas que regiam o SUS, recomendavam aos juízes que considerassem essas normativas organizativas específicas do SUS em

\footnotetext{
${ }^{29}$ Os enunciados enviados para primeira Jornada não são públicos. A lista completa dos enunciados enviados pode ser encontrada nos anexos dessa dissertação.

${ }^{30}$ Os enunciados aprovados podem ser encontrados no anexo dessa dissertação
} 
suas decisões, recomendava que os juízes pedissem comprovações de que o quadro clínico do paciente não pode ser atendido por políticas públicas já estabelecidas, e recomendava que os juízes não concedessem medicamentos não registrados na ANVISA, medicamentos em fase experimental ou medicamentos para uso off-label. Dos enunciados aprovados na II Jornada, 9 dos 15 tinham um teor muito semelhante aos aprovados na I Jornada, recomendando a observância das normativas que estruturam o SUS e das políticas públicas já vigentes. Um grupo de enunciados, no entanto, diz respeito ao cumprimento de medidas liminares pelos órgãos públicos, em especial sobre valores depositados em conta judicial e bloqueio do numerário por ordem judicial.

O segundo desdobramento dos Encontros e das Jornadas foi de cunho relacional: ocorreu uma ampliação do debate com atores não pertencentes ao sistema de justiça, que culminou em uma ampliação da composição do Fórum, que se deu "de fora para dentro". Conforme relatado por todos os entrevistados, a dinâmica dos debates ocorridos nos encontros, especialmente em 2011, foi muito particular. O espaço, organizado pelo Poder Judiciário e com mesas de debate cujos debatedores eram magistrados, em sua maioria, transformou-se em palco para exposição de gestores do SUS. Fernanda Terrazas, que participou dos Encontros como representante do CONASEMS e desde 2013 representa a mesma instituição como membro do Comitê Executivo Nacional do Fórum da Saúde, relatou em entrevista que, enxergando nos Encontros uma arena de intelocução com os operadores do direito, representantes do Ministério da Saúde, do CONASS e do CONASEMS se organizaram previamente para estarem presentes e ocuparem os debates. Ainda de acordo com Terrazas, à época, críticas foram feitas aos Encontros justamente pela percepção, pelos magistrados, de que o debate estava sendo dominado pelos gestores, em um espaço que havia sido organizado, a priori, pelos e para os magistrados e operadores do Direito. Essa percepção foi confirmada em entrevista por Rodrigo Rocha, servidor do CNJ e que atua como assessor do conselheiro supervisor do Fórum, em sua instância nacional, desde 2010. De acordo com Rocha, o clima sentido nas primeiras experiências do Encontro era de uma posição muito conflituosa entre gestores e juízes, em que a culpa pela judicialização do direito à saúde era atribuída por um grupo ao outro. Essa dinâmica viria a mudar para uma posição mais cooperativa nos anos seguintes.

Da dinâmica relacional estabelecida durante os debates, houve um movimento de pluralização da composição do Fórum, por demanda dos atores que se enxergavam como partes interessadas na discussão, mas que não se viam representados na 
composição do Fórum. Fernanda Terrazas (CONASEMS) e Alethele Santos (CONASS), ambas membros do Fórum desde 2013 e que participaram desse movimento de solicitação de representação dessas instâncias na iniciativa do CNJ, concordam ao exporem os motivos que fizeram esses órgãos requererem participação ativa no órgão como membros, e não só participação eventual nas iniciativas do Fórum como participantes dos Encontros: em suas visões, oferecidas nas entrevistas, o Fórum estava se mostrando como uma instância capaz de organizar o debate e mudar a maneira como a judicialização do direito à saúde era entendida pelos operadores do Direito. E apenas a voz do Ministério da Saúde estava sendo ouvida, o que não representava fielmente a maneira como o SUS se organiza, ou seja, de forma tripartite. O pedido para integrar o Fórum se pautou principalmente no fato de que as esferas municipais e estaduais precisavam ser contempladas nas discussões para oferecerem a visão dos gestores que de fato lidavam com a judicialização e implementavam grande parte das políticas de saúde, e que a escuta apenas do Ministério da Saúde levaria a um diagnóstico incompleto.

A solicitação para a inclusão de representantes das outras instâncias do SUS como membros permanentes do Fórum partiu oficialmente do CONASEMS- mas em articulação com o CONASS, que foi atendida sem entraves. O coordenador do Fórum à época, juiz Fernando Mattos, solicitou que os próprios órgãos indicassem seus representantes para compor o Fórum. Tanto CONASS como CONASEMS indicaram suas assessoras jurídicas, de forma a criar uma interlocução mais fluida dentro de um órgão mantido pelo Poder Judiciário.

Outro resultado das atividades do Fórum dessa primeira fase é a elaboração de enunciados pelos Comitês Executivos Estaduais, que contemplam resumos de iniciativas bem-sucedidas e sugestão de adoção de tais medidas por atores do sistema judicial e do sistema de saúde - uma espécie de benchmarking dos tribunais. Alguns comitês estaduais também elaboraram cartilhas informativas direcionadas a esclarecer e informar os magistrados sobre tópicos específicos, por exemplo, a política oncológica do SUS, o processo para inclusão de novo protocolo clínico e diretrizes terapêuticas (PCDT) no SUS. 
Retrabalhando o modus operandi do Fórum: Aproximação interinstitucional e foco nos NATs

De todos atores entrevistados para essa pesquisa, três acompanharam o Fórum desde sua instalação até a presente fase:

i) Rodrigo Rocha, servidor do CNJ que assessora sempre o supervisor do Fórum e acompanha as reuniões do Comitê Executivo, além de auxiliar na parte operacional das iniciativas deliberadas nessa arena;

ii) Maria Inez Gadelha, médica e representante do Ministério da Saúde no Comitê Executivo Nacional em todas as suas composições;

iii) Desembargador João Pedro Gebran Neto também fez parte do Fórum desde sua instalação, inicialmente como membro do comitê estadual de Saúde - PR e depois como membro do Comitê Executivo Nacional, a partir de 2014.

Do ponto de vista da dinâmica entre os membros do Fórum, os três entrevistados fizeram uma caracterização muito semelhante da evolução das discussões e interações nas reuniões do Fórum, que se refletiram nas iniciativas privilegiadas pelo Comitê Executivo Nacional. Inicialmente, quando da instalação do órgão, havia um caráter proeminentemente organizador da judicialização e uma tentativa de racionalizar esse tema, para dar conta do volume crescente de ações que chegavam ao Judiciário. As experimentações com os Encontros, que privilegiaram os operadores de Direito nas discussões, representavam uma tentativa de contextualizar o debate e entender as diversas experiências dos magistrados com a temática.

O impacto no orçamento público permeava o debate, mas o tópico nunca tomou lugar central nas discussões, nem foi foco de qualquer ação específica do órgão. A composição inicial do Fórum - basicamente composta por membros da magistratura, excluindo outros operadores do Direito (como membros do Ministério Público e Defensoria Pública, por exemplo) e gestores de Saúde (lembrando que a participação do Ministério da Saúde foi requisitada por esse, e não prevista inicialmente pelo Grupo de Trabalho que organizou e propôs a instalação do Fórum da Saúde) - era um espelho da principal preocupação e estava à serviço de quem foi o primeiro responsável pela implementação do órgão.

Com a inclusão de novos atores a partir de 2012, especialmente representantes dos gestores e profissionais de saúde pública, as discussões se encaminharam para o 
confronto. As representantes do CONASEMS e do CONASS, Fernanda Terrazas e Alethele Santos, apresentaram versões parecidas das dinâmicas dentro do Fórum: à princípio, ao verem que "a versão do gestor não era contemplada nas discussões", procuraram trazer o contraponto nas reuniões. No entanto, a postura combativa e dura apresentada - a mesma que havia gerado incômodo nos Encontros, mas que havia lhes garantido entrada no Fórum - foi mal recepcionada. Maria Inez Gadelha, representante do Ministério da Saúde, observa que a "postura era muito sectária de ambos os lados" [gestores e magistrados]. Para ela, questões importantes como a maneira como SUS era estruturado, seu funcionamento e para quantos o sistema era direcionado não eram levadas em consideração pelos juízes. Diz Gadelha "a justiça havia virado refém das ações, que não levavam em conta esses outros fatores".

$\mathrm{Na}$ condição de observador das reuniões, Rodrigo Rocha viu na postura das representantes que não eram da magistratura um entendimento de que o Fórum poderia impor coisas aos juízes, sem perceber - a seu ver - que o papel do CNJ não era dar norte ao juiz, mas sim auxiliar a jurisdição.

As representantes da gestão, então, perceberam que ali se tratava de um Fórum do e para o Judiciário, e que havia um limite para a contribuição da gestão: as propostas e iniciativas tinham que vir dos magistrados, e as representantes da gestão precisariam auxiliar e colocar fatores de ponderação para que a saída encontrada fosse a mais plural possível $^{31}$. Entre 2012 e 2014, o órgão amadurece e a discussão de mérito acerca de quem deveria ser o culpado pela excessiva judicialização desaparece, abrindo caminho para discussões para achar caminhos e soluções possíveis. Terrazas sumariza esse período como tendo sido necessário para "desestigmatizar os dois lados, e focar as discussões em soluções para o dia a dia, e menos em questões paradigmáticas”. João Pedro Gebran Neto, que começa a participar do Comitê Nacional apenas em 2014, já relata experiências apenas de cooperação entre os membros: "Impera um espírito republicano nas reuniões. Não há tentativas de convencimento de nenhum dos lados, mas sim apresentação de caminhos - sem discussão de mérito".

Entre 2014 e 2016, os membros do Comitê Nacional já estavam em uma sintonia mais fina, superada a fase mais combativa, uma postura mais cooperativa foi ganhando espaço, muito em razão de um entendimento pacificado em relação à

\footnotetext{
${ }^{31}$ No entanto, ao constatarem isso, também criam um lócus institucional de debate dentro do Ministério da Saúde e na CIT/CIB (instâncias gestoras do SUS) para se discutir os avanços alcançados pelo próprio Fórum da Saúde ${ }^{31}$. Diz Terrazas "há uma retroalimentação entre o Fórum e as Comissões Intergestores Tripartite e Bipartite"
} 
existência de diferentes tipos de judicialização do direito à saúde, e aos diferentes efeitos de cada um dos tipos. Todos os entrevistados categorizaram de forma muito similar a judicialização do direito à saúde na saúde pública, e seus efeitos positivos e negativos: haveria a judicialização de tratamentos não autorizados pela ANVISA, de tratamentos já registrados, mas ainda não avaliados ou já avaliados pela CONITEC e não incorporados aos SUS e a judicialização de tratamentos incorporados pelo SUS, mas que não estavam sendo ofertados. Todos são unânimes em dizer que esse último tipo de judicialização sim é legítima e tem aspectos positivos, pois ajuda a corrigir falhas do sistema, já que nessas situações uma política pública existe, mas não está sendo efetivada. Nas palavras de Maria Inez Gadelha: "uma ação judicial assim [da última categoria] é positiva, pois tem caráter estruturante". Um dado extremamente simbólico desse novo entendimento foi o abandono do slogan inicial do Fórum "a Justiça faz bem à saúde", que resumia a concepção inicial do Judiciário de que qualquer judicialização fazia "bem à saúde", de acordo com Fernanda Terrazas, do CONASEMS.

Foi nesse período, a partir de 2014, que dois coordenadores estaduais ${ }^{32}$ também foram indicados para integrar o Comitê Nacional e, assim, levaram tanto as experiências bem-sucedidas, como os NATs, como relatos de falta de proximidade e apoio prático da instância Nacional em relação aos comitês estaduais. A falta de proximidade do Comitê Nacional com o nível estadual também foi sentida pelos gestores: em uma reunião do CONASS em março de 2015, em que o Fórum requereu participação para ampliar o diálogo com os gestores, houve reclamações de vários secretários estaduais de saúde da falta de diálogo com o Judiciário.

Tendo isso em vista, a então supervisora do Fórum, Deborah Ciocci, além de encaminhar a II Jornada de Direito à Saúde em 2015, estabeleceu um “giro do Fórum”: representantes do Fórum Nacional de Saúde visitariam todas as unidades da federação até o fim daquele ano. O objetivo era apoiar os comitês estaduais na implementação dos NATs e também aproximar o Fórum das secretarias estaduais de saúde.

Apesar de previsto na Resolução 31/2010, os Núcleos de Apoio Técnico (NATs) tiveram implementação muito incipiente até 2016, sem diretrizes específicas do Comitê Executivo Nacional, cujo foco repousou na organização do debate e em criar um diálogo e entendimento entre atores do sistema de justiça e do sistema de saúde pública.

\footnotetext{
${ }^{32}$ Renato Dresch (MG) e João Pedro Gebran Neto (PR)
} 
Até 2014, alguns NATs já haviam sido constituídos seguindo a recomendação contida na Resolução 107/2010 e a própria Recomendação 31/2010. Esses núcleos tinham propósitos parecidos, mas dinâmicas por vezes distintas, muito em razão da sua implementação ter ficado a cargo de alguns comitês estaduais, especialmente pelos comitês do Rio Grande do Sul, Paraná, Minas Gerais e Tocantins, que estruturaram a organização desses núcleos com os recursos materiais e relacionais que cada um tinha.

Os Núcleos de Apoio Técnico (NATs), formados por profissionais da área médica, farmacêutica e por membros das Secretarias Estaduais e Municipais de Saúde, tem como principal função auxiliar os magistrados na deliberação sobre processos envolvendo demandas de direito à saúde. Os NATs funcionam por demanda dos juízes, que, em recebendo uma ação judicial com temas envolvendo saúde, podem solicitar manifestação do órgão sobre os documentos que compõem o processo, como a petição inicial e relatórios médicos. Os NATs expedem pareceres técnicos, específicos para o caso em vista, que contam, por exemplo, com informações acerca do registro (ou ausência dele) na Anvisa, avaliação de questões clínicas, como eficácia e eficiência do tratamento solicitado para a doença do paciente, sobre alternativas de tratamento existentes no SUS e sobre o custo-efetividade do tratamento pedido na ação.

É importante destacar que a atuação dos NATs se dá sob as demandas já judicializadas, e os pareceres técnicos têm como principal objetivo qualificar a decisão do juiz. Esses pareceres são posteriormente organizados em um acervo para consulta pública, o que pode auxiliar juízes que tenham casos parecidos em mãos, mas que ainda não contam com um órgão técnico consultivo para auxiliá-lo. Além disso, esses pareceres disponibilizados publicamente também têm um efeito cumulativo de facilitar a defesa dos entes públicos. No entanto, maneiras criativas de estruturar um fluxo pelo qual uma ação de demanda de direito à saúde passa pode dar uma resolução administrativa, e não judicial, para o caso - como o exemplo da estrutura criada em torno do NAT de Araguaína demonstrou. Para tanto, foi especialmente importante o reconhecimento da importância desse órgão e de seu objetivo pelos gestores de saúde e seu engajamento na iniciativa, para formar uma rede de cooperação entre Judiciário e Executivo.

Com a mudança de supervisor do Fórum em 2016, passando para o Conselheiro Arnaldo Hossepian - representante do Ministério Público - os NATs passam a ser a principal frente de trabalho do Comitê Executivo Nacional, que enxergava nos núcleos um instrumento para "descer" as discussões que eram feitas há 
anos no âmbito do Comitê Nacional e criar interlocução com os atores que estavam na ponta, que poderiam efetivamente trazer resolutividade. Para Hossepian, a coordenação vertical no entendimento de qual judicialização é a "boa judicialização" pela magistratura não se dá por iniciativas no campo normativo: "Existe uma necessidade de compreender e convencer o juiz, e isso não se dá por enunciados. Juiz não segue enunciados, juiz só segue súmula [vinculante]. A maneira de ajudar o juiz a decidir de forma mais qualificada não é se metendo na jurisdição, mas oferecendo ferramenta rápida para acesso ao conhecimento especializado. Precisamos dar suporte adequado ao juiz".

Após algumas visitas do Comitê Nacional a comitês estaduais que tinham NATs funcionando com vistas a conhecer boas práticas, o CNJ editou a Resolução 238/2016, uma espécie de reformulação da Resolução 107/2010, com a intenção de constituir e consolidar os comitês estaduais, assim como a implementação dos NATs, que já havia sido sugerida pela Recomendação 31/2010.

Hossepian enfatiza a importância de uma estrutura descentralizada do Fórum, dado que cada estado tem perfil e necessidade diferentes, de forma que comitês locais se constituem na melhor maneira de se atingir o objetivo de identificar os problemas regionais e propor adoção de inovações na busca de soluções para problemas mais prementes regionalmente. Nesse sentido, a estrutura do Fórum, atualmente, espelha a organização do próprio SUS, que tem no Ministério da Saúde o organizador das políticas públicas de saúde e fomentador de sua implementação, mas que opera de forma descentralizada, dada a necessidade de adequação à realidade local na forma em que as políticas serão entregues à população.

Os atos normativos foram importantes para estabelecer formalmente a replicação de experiências práticas que já vinham dando certo: tanto os comitês estaduais quanto os NATs. Mas, para além de edição das normativas, o que mais fez decolar essa iniciativa foi a possibilidade de mobilização de recursos relacionais a que o Comitê Nacional tinha acesso, e que não estavam ao alcance de muitos comitês estaduais. A instância nacional fez acordos de cooperação técnica com o Ministério da Saúde em 2016, além de mobilizar recursos de um programa do SUS, o PROADI-SUS (Programa de Apoio ao Desenvolvimento Institucional do Sistema Único de Saúde). A intenção é criar um grande banco de dados à disposição dos magistrados, a partir dos laudos produzidos pelos NATs, com análises baseadas em evidências científicas, 
garantidas pelo Centro Cochrane do Brasil ${ }^{33}$. Além disso, a capacitação dos integrantes dos NATs está a cargo do Hospital Sírio-Libanês, em São Paulo, que investirá, por meio do PROADI-SUS, cerca de R\$ 15 milhões, ao longo de três anos, para criar a estrutura da plataforma. O CNJ tem como papel coordenar as ações, resguardar as informações e torná-las acessíveis aos juízes.

\subsection{Conclusão}

A primeira hipótese que orientou esse trabalho foi que a instalação do Fórum teve por objetivo uniformizar verticalmente o entendimento das questões relacionadas a demandas em saúde, isto é, entre o STF e as instâncias inferiores do Poder Judiciário. A segunda hipótese foi que a instalação do Fórum também objetivou uma uniformização horizontal entre os poderes, isto é, uma coordenação entre o Judiciário e diversos órgãos do poder Executivo e demais atores institucionais envolvidos com a questão.

Ao analisarmos a trajetória do Fórum e suas iniciativas, argumentamos que essa arena, que inicialmente incluia apenas membros do Poder Judiciário e que, com o tempo, foi crescendo em representatividade e em atuação, conquistou para si um nível de autoridade prática ao engajar novos atores, instaurar novas instâncias dentro da organização do Judiciário, os NATs, com vistas a construir novas capacidades técnicas para os juizes e, de alguma forma, aumentar o diálogo com o Poder Executivo.

No que diz respeito à primeira hipótese, relativa a uma busca de uniformização vertical do comportamento do Judiciário, nossa pesquisa indica que o Fórum parece estar agindo nesse sentido. Todavia, antes da uniformização propriamente dita e para poder alcança-la, os primeiros passos foram descentralizar sua estrutura por meio dos comitês estaduais e realizar o esforço de instalação dos NATs em todos os estados da federação. Ao disseminar um novo entendimento sobre os diferentes tipos de ação que demandam assistência à saúde, ao contextualizá-las dentro das políticas públicas vigentes, e ao incentivar uma decisão dos juízes mais contextualizada e baseada em evidências - colocando à disposição dos tribunais, de forma regionalizada, os NATs, há boas chances do Forum alcançar a uniformização almejada.

\footnotetext{
${ }^{33}$ De acordo com o site do Cochrane Brasil, "O Cochrane Brasil é uma organização não governamental, sem fins lucrativos e sem fontes de financiamento internacionais, que tem por objetivo contribuir para o aprimoramento da tomada de decisões em Saúde, com base nas melhores informações científicas disponíveis. Sua missão consiste em elaborar, manter e divulgar revisões sistemáticas de ensaios clínicos randomizados, o melhor nível de evidência para tomada de decisões em saúde.” Site: http://brazil.cochrane.org/
} 
Por outro lado, como procuramos argumentar, a independência judicial decisonal não permite, via de regra, uma imposição por via normativa de uma maneira de decidir ${ }^{34}$. Portanto, uma uniformização da jurisprudência é algo a ser construído aos poucos e e cumulativamente ao longo do tempo. Ao tornar o debate acerca dessa questão mais próximo dos magistrados e incluir novas vozes nessa discussão, em conjunto com a oferta de maior capacitação institucional para apoiar as instâncias inferiores, o Fórum vem conseguindo que os juízes de primeiro e segundo graus revejam sua maneira de fazer as coisas, pela via do convencimento. Isso só foi possível, como argumentamos ao longo do capítulo, pelo desenvolvimento de autoridade prática ao longo dos anos. Apesar de não haver ainda dados compilados sobre isso, as entrevistas com os coordenadores de comitês estaduais já revelam que, ainda que não uma uniformização na jurisprudência, as ações do Fórum atingiram, ao menos, uma diminuição na variação das decisões.

No que diz respeito à segunda hipótese, o Fórum possibilitou uma interação qualificada e capaz de superar impasses na relação com o Poder Executivo. Ao engajar esses atores, trazê-los para o debate e, ao mesmo tempo, se dispor a participar nas instâncias deliberativas do SUS, o Fórum parece ter amenizado a postura confrontativa entre gestores e juízes em prol de uma postura de cooperação e entendimentos compartilhados. Caso venha a ter êxito na promoção da interação com o Executivo e demais atores institucionais envolvidos com a questão da saúde, não cabe dúvida de que o Forum representará uma nova fase no ciclo da judicialização, ainda hoje muito marcado pela ideia de confrontação entre poderes, de usurpação de funções e por distorções da representação política. Não que o Fórum terá o condão de eliminar todos os elementos contraditórios, talvez intrínsecos ao fenômeno, mas certamente representará um patamar de coordenação horizontal até hoje inexistente em todas as áreas de políticas públicas sujeitas à judicialização.

\footnotetext{
${ }^{34}$ A edição de súmula vínculante pelo STF, em raros casos, pode tornar uma determinada interpretação de observância obrigatória para as instâncias inferiores.
} 


\section{CONSIDERAÇÕES FINAIS}

A literatura de judicialização de políticas públicas se concentra em discutir se há ou não um possível ativismo judicial dos juizes ao decidirem ações dessa natureza e a caracterizar, quantitativa e qualitativamente, as ações que chegam ao judiciário. Baseamo-nos aqui na ideia de ciclo de judicialização formulada por Oliveira (2005), que leva em conta critérios empíricos para determinar se houve ou não judcialização de uma determinada política pública, entendida como uma decisão do Judiciário que vai de encontro com a ação do Executivo, alterando o status quo vigente. Abordando um tipo específico de políticas públicas - as políticas sociais, na qual a política de saúde se inclui - Gauri \& Brinks (2008) caracterizam como o litígio se dá, com a provocação do judiciário, a reação do gestor, e novas ações provocando o judiciário, em um ciclo pendular constante, o qual chamam de legalization. Mas a literatura de judicialização de políticas públicas leva em conta o papel do Judiciário em sua função jurisdicional, isso é, sua atuação ao decidir ações e suas manifestações no processo judicial. O que avaliamos nesse trabalho, as iniciativas do Fórum da Saúde, parecem avançar em relação ao que a literatura considera como sendo judicialização. Talvez estejamos diante de uma nova fase, informada pela judicialização, mas que seja pós-judicialização.

Entendendo o Fórum como um lócus institucional do qual partem ações e medidas concebidas por atores jurídicos sobre políticas públicas na área de saúde, suas ações e medidas parecem ultrapassar as fronteiras conhecidas do próprio ciclo de vida da judicialização: o Poder Judiciário se arvora para além da atuação jurisdicional, buscando, através da coordenação entre atores do sistema de justica com o Judiciário, e do Judiciário com atores do poder Executivo, ter a palavra final no movimento pendular de legalization. Dessa forma, tratou de uma nova fase no ciclo tradicionalmente conhecido da judicialização, que foi a iniciativa da própria justiça de ingressar, pela via administrativa de seu Conelho Nacional de Justiça, no âmbito do que se poderia chamar de a própria formulação da política, mas desta feita a partir e mediante a sua própria liderança.

Isso parece estar sendo feito, por um lado, por meio da construção de capacidade institucional e gerencial do próprio Poder Judiciário, e, por outro, através do estabelecimento de diálogo entre o sistema judicial e de saúde, sendo o Fórum um lócus participativo e plural em sua composição. Em outras palavras, a judicialização que conhecemos tem se dado em sede de processos judiciais. A inaugurada pelo Fórum não 
se restringe aos processos e visa, desde o campo da administração da justiça, influenciar no desenho e no alcance das políticas públicas no campo da saúde.

Fueller (1978) discute a limitação do modelo de arbitramento adversarial do processo para a resolução do que ele chama de "tarefas policêntricas", objetos complexos que englobam análises de fatores externos à teoria jurídica, como é o caso de políticas públicas. Ao estabelecer formas e ações que extrapolam os processos judiciais, o Judiciário passa a ter a potencialidade de ser, ele mesmo, um fórum em que normas são criadas e aplicadas através de um processo deliberativo. A instalação do Fórum pelo poder Judiciário representou uma proposta do Judiciário para si mesmo, de um novo método de decidir, que vai além do método judicial e se confunde ele mesmo com o método de uma política pública.

Ripley (1995) propos que o processo de formulação e estabelecimento de uma política pública se dava em cinco estágios: 1) estabelecimento de agenda; 2) formulação e legitimação dos objetivos da política; 3) implementação da política; 4) avaliação da política e 5) decisões acerca do futuro da política. Embora o próprio autor chame a atenção para o fato de que essas etapas não são sucessivas entre si, mas sim acontecem de foma sobreposta, o modelo analítico proposto é amplamente usado nos estudos de análise de políticas públicas. Ao olharmos como o Fórum se organizou, percebemos que os estágios de formulação e implementação de uma política pública propostos por Rippley (1995) são nítidos: a organização dos Encontros e das Jornadas permitiu a discussão com diversos atores e a captação de opiniões dissidentes para formular um entendimento mínimo comum entre eles. Juntamente com as reuniões dos comitês, com especial atenção para o Comitê Executivo Nacional, uniformizou-se o entendimento sobre quais tipos de judicialização eram negativos e qual tipo era positivo, e se decidiu dar prioridade ao estabelecimento dos NATs regionalizados por Tribunais de Justiça nos estados, como forma de uniformizar o entendimento, entre os atores do Judiciário, acerca de quais ações com temáticas de saúde eram legítimas, aqui entendidas como o tipo de judicialização com potencial estruturante e de correção de falhas do sistema público de saúde, e quais ações não deveriam ser concedidas, levando-se em conta as políticas públicas e organização do sistema de saúde e vigilância sanitária vigentes no país. O sistema de monitoramento de demandas judiciais proposto pelo Fórum, embora ainda muito incipiente, pretende acompanhar as demandas e, também, ser uma medida de avaliação do impacto da implementação dos NATs. 
Apesar de concebido por e para os atores jurídicos, o Fórum da Saúde foi capaz de trazer para sua órbita de influência toda uma área de políticas públicas, incluindo atores do Executivo de diversas esferas e outros operadores do direito. Embora as ações ali concebidas objetivem, pelo menos de acordo com o discurso coletivo explícito dos atores que o compõem, melhorar a prestação jurisdicional, as iniciativas e debates fomentados nessa arena têm impacto também no sistema de saúde, seja na mudança de mentalidade dos gestores, seja em sua própria organização. Os próprios NATs, que são coordenados pelo Judiciário e estão a serviço desse órgão, são compostos por membros cedidos pelas secretarias da saúde. Além disso, os comitês estaduais também estabelecem fluxos próprios de interação entre os juizes e tribunais com os órgãos de gestão do SUS, criando redes de cooperação para tentar dar soluções administrativas para processos judiciais.

Ao analisar essa nova dinâmica inaugurada pelo Fórum, Santiago (2016) propõe uma perspectiva crítica sobre essa atuação. Ao retomar a mentalidade do Movimento Sanitarista Brasileiro que presidiu a noção de direito à saúde e organização do sistema público de saúde constitucionalizados na Carta de 1988, a autora retoma a previsão de participação popular na estruturação da política pública de saúde, através dos conselhos participativos, de forma a dar concretude ao conceito de democracia sanitária. As ações do Fórum, no entanto, teriam - para Santiago (2016) - diminuído o poder de controle e participação social em políticas de saúde. Para a autora:

Essa esfera [o Fórum da Saúde], controlada pelo Judiciário, não tem vislumbrado a necessidade de articulação com os canais participativos oficialmente instituídos pela política, que são os conselhos gestores. No caso da saúde, o protagonismo político dos juízes entra em disputa direta com o poder político sobre o controle das decisões. Essa esfera tem apontado para o enfraquecimento da noção coletiva de saúde e o fortalecimento do atendimento das necessidades individuais. (SANTIAGO, 2016, p. 216)

De fato, o Fórum tem se mostrado, como argumentamos ao longo desse trabalho, uma instituição útil para resolver problemas que outras instituições, como os conselhos gestores, não conseguiam. Em seu trabalho, Santiago (2016) entrevistou apenas magistrados que compõem o Fórum, não dando escuta às percepções dos membros que representam o Ministério da Saúde, o CONASS e o CONASEMS - 
órgãos que compõem a estrutura decisória do SUS. Em nossa análise do Fórum, ao incorporarmos também a percepção desses atores acerca da atuação dessa istância, fizemos o argumento de que, através de uma série de práticas concretas e engajamento de diversos atores, o que inclui atores do Poder Executivo, o Fórum transformou a dinâmica pendular entre Executivo e Judiciário, ao criar mecanismos eficazes e reconhecidos de diálogo, além de ter proposto iniciativas que deram certo e são reconhecidas como úteis também para os interesses da própria gestão do SUS.

Caberia também salientar que, ao ter representantes do CONASS e CONASEMS em sua composição, além da participação de gestores das secretarias nos comites estaduais, os interesses coletivos estariam de alguma forma ali representados, visto que essas instâncias de gestão do SUS (secretarias municipais e estaduais de saúde) também coordenam os conselhos gestores e, portanto, tiram dali os consensos e os levam ao Fórum. O recente movimento do Fórum de também estar presente nas reuniões do CONASS e nas reuniões dos Conselho Intergestores Tripartite poderia também ser interpretado, ainda que como uma hipótese a ser investigada futuramente, que o Fórum tem se mostrado não um mecanismo de esvaziamento das instâncias de controle participativo, mas sim como um mecanismo de ampliação dos atores que formulam as políticas públicas de saúde.

O presente estudo teve como principal contribuição analisar as origens da iniciativa e formular linhas de investigação pra pesquisas futuras. Ainda que não possamos afirmar de forma definitiva se o Fórum promoveu uma real coordenação vertical e/ou horizontal, pois isso dependeria de um estudo mais aprofundado sobre sua performance efetiva, através da análise de dados consolidados acerca do real impacto das iniciativas do Fórum no volume e natureza das resoluções que são dadas às ações judiciais que demandam assistência à saúde, essa instituição representa, desde já, um passo a mais na judicialização da política no Brasil. 


\section{REFERÊNCIAS BIBLIOGRÁFICAS}

ABERS, R. N.; KECK, M. E. Practical authority: Agency and institutional change in Brazilian water politics. Oxford University Press, 2013.

ARANTES, R. B. Judiciário e Política no Brasil. São Paulo: Idesp, 1997.

Consensos e Dissensos na Reforma Constitucional do Judiciário. In:

PINHEIRO, A. C. (Org.). Reforma do Judiciário. Problemas, desafios, perspectivas. Rio de Janeiro: Booklink, p. 120-137, 2003.

Judiciário: entre a justiça e a Política. In: AVELAR, L; CINTRA, A. Sistema político brasileiro: uma introdução. São Paulo: Editora Unesp, 2015.

ATRIA, F. ¿Existen Derechos Sociales? Revista Discussiones, n. 4, 2004. Disponível em:

$<$ http://descargas.cervantesvirtual.com/servlet/SirveObras/0182663054903611 4110035/015570.pdf?incr=1>. Acesso em: 27 nov, 2017.

BARCEllos, A. P. O Direito a Prestação de Saúde: Complexidades, Mínimo Existencial e o Valor das Abordagens Coletiva e Abstrata. In: SARMENTO, D; SOUZA NETO, C. P. Direitos Sociais - fundamentos, judicialização e direitos sociais em espécie. Rio de Janeiro: Lumen Juris, 2010.

BIEHL, J. et al. Between the court and the clinic: lawsuit for medicines and the right to health in Brazil. Health and Human Rights. v. 14, n. 1, p. 36-52, 2012.

BORGES, D. C. L. Uma análise das ações judiciais para o fornecimento de medicamentos no âmbito do SUS: o caso do Estado do Rio de Janeiro. 2007. 117 p. Dissertação (Mestrado em Saúde Pública). Escola Nacional de Saúde Pública Sérgio Aruoca / ENPS, Fundação Oswaldo Cruz / Fiocruz, Rio de Janeiro, 2007. 
BRASIL. Conselho Nacional de Justiça. Recomendação n. 31, de 31 de março de 2010. Disponível em:

<http://www.cnj.jus.br/images/atos_normativos/recomendacao/recomendacao _31_30032010_22102012173049.pdf>. Acesso em: 20 jun. 2016.

BRASIL. Conselho Nacional de Justiça. Resolução n. 107, de 6 de abril de 2010. Disponível em:

<http://www.cnj.jus.br/images/atos_normativos/portaria/portaria_91_11052010 _18102012202412.pdf>. Acesso em: 20 jun. 2016.

BRASIL. Conselho Nacional de Justiça. Portaria n. 91, de 1 de maio de 2010. Disponível em:

<http://www.cnj.jus.br/images/atos_normativos/resolucao/resolucao_107_0604 2010_11102012191858.pdf >. Acesso em: 20 jun. 2016.

BRASIL. Conselho Nacional de Justiça. Portaria n. 40, de 25 de março de 2014. Disponível em:

<http://www.cnj.jus.br/images/atos_normativos/portaria/portaria_40_25032014 _27032014134822.pdf>. Acesso em: 20 jun. 2016.

BRASIL. Constituição (1988). Constituição da República Federativa do Brasil. Brasília, DF: Senado, 1988.

BRASIL. Supremo Tribunal Federal. 'Abertura. Audiência Pública n. 4'. 2009. Disponivel em: <http://www.stf.jus.br/arquivo/cms/processoAudienciaPublicaSaude/anexo/A bertura_da_Audiencia_Publica_MGM.pdf>.Acesso em: 20 jul, 2016.

CALIL, M. L. G. Efetividade dos Direitos Sociais. Porto Alegre: Nuria Fabris, 2012.

CANOTILHO, J. J. G. Constituições dirigentes e vinculação do legislador: contributo para a compreensão das normas constitucionais programáticas. Coimbra: Coimbra Editora, 1994. 
CARVALHO, A. D. S. A efetivação dos direitos à saúde pública: uma análise do Poder Judiciário no Brasil. 2013. 184 p. Tese (Doutorado em Ciência Política). Centro de Educação e Ciências Humanas, Universidade Federal de São Carlos, São Carlos, 2013.

CASTRO, S. H. R. Impacto desalocativo no orçamento público estadual em face de decisões judiciais. Fórum de Contratação e Gestão Pública, Belo Horizonte, v. 15, n. 169, jan. 2016. Disponível em: <http://dspace/xmlui/bitstream/item/21456/Sebasti\%c3\%a3o\%20Helv\%c3\%a 9cio.pdf?sequence=1>. Acesso em: 25 fev, 2016.

CENEVIVA, R. Accountability: novos fatos e novos argumentos-uma revisão da literatura recente. Anais do Encontro de Administração Pública e Governança da Associação Nacional de Pós-Graduação e Pesquisa em Administração, p. 1-17, 2006.

CHIEFFI, A.; BARATA, R. Judicialização da política pública de assistência farmacêutica e equidade. Cad. Saúde Pública, Rio de Janeiro, v. 25, n, 8, p. 1839-1849, 2009.

COUTO, C. G.; ARANTES, R. B. Constituição, governo e democracia no Brasil. Revista Brasileira de Ciências Sociais, v. 21, n. 61, p. 41-62, 2006.

DA ROS, L. O custo da Justiça no Brasil: uma análise comparativa exploratória. Newsletter. Observatório de elites políticas e sociais do Brasil. NUSP/UFPR, v. 2, p. 1-15, 2015.

ENGELMANN, F.; CUNHA FILHO, M. C. Ações judiciais, conteúdos políticos: uma proposta de análise para o caso brasileiro. Revista de Sociologia e Política, v. 21, n. 45, p. $57-72,2013$.

EPSTEIN, L e KNIGHT, J. The Choices Justices Make. Washington, DC: CQ Press, 1998. 
FANTI, F. Políticas de saúde em juízo: um estudo sobre o município de São Paulo. 2009. 106 p. Dissertação (Mestrado em Ciência Política). Faculdade de Filosofia e Ciências Humanas, Universidade de São Paulo, São Paulo, 2009.

FEREJOHN, J. Accountability and authority: toward a theory of political accountability. Democracy, accountability, and representation, v. 131, p. 133, 1999.

FERRAZ, O. L. M. Brazil. Health inequalities, rights and courts: the social impact of the judicialization of health. In: YAMIN, A. E.; GLOPEN, S. Litigating the Right to Health. Cambridge, Harvard University Press, 2011.

; VIEIRA, F. S. Direito à saúde, recursos escassos e equidade: os riscos da interpretação judicial dominante. Revista de Ciências Sociais, v. 52, n. 1, p. 223-251, 2009.

FRAGALE FILHO, Roberto. Conselho Nacional de Justiça: Desenho Institucional, Construção de Agenda e Processo Decisório. DADOS, Revista de Ciências Sociais, Rio de Janeiro, v. 56, n. 4, p. 975-1007, 2013.

FULLER, L. The Forms and Limits of Adjudication. Harvard Law Review, v. 92, n. 2, p. 353-409, 1978.

GARGARELLA, R. Dialogic justice in the enforcement of social rights: some initial arguments. In: YAMIN, E.; GLOPPEN, S. Litigating the Right to Health. Cambridge: Harvard University Press, 2011.

GAROUPA, N.; GINSBURG, T. Judicial Audiences and Reputation: Perspectives from Comparative Law. Colum. J. Transnat'l L., v. 47, p. 451, 2008.

GAURI, V; BRINKS, D. Courting Social Justice: judicial enforcement of social and economic rights in the developing world. New York: Cambridge University Press, 2008. 
GEYH, C. G. Judicial Independence, Judicial Accountability, and the Role of Constitutional Norms in Congressional Regulation of the Courts. Ind. LJ, v. 78 , p. $153,2003$.

HIRSHL, R. The Judicialization Of Politics. In: CALDEIRA, G. A.; KELEMEN, R. D.; WHitTingtON, K. E. (orgs). The Oxford Handbook of Law and Politics. Oxford University Press, 2000.

KING, J. Judging Social Rights. Cambridge: Cambridge University Press, 2008.

MACHADO, M. A. A. et al. Judicialização do acesso a medicamentos no Estado de Minas Gerais, Brasil. Revista de Saúde Pública, v. 45, n. 3, 2011.

MALUF, P. J. L. Conselho Nacional de Justiça: análise de sua competência disciplinar. 2013. 184 p. Dissertação (Mestrado em Direito do Estado) Faculdade de Direito, Universidade de São Paulo, São Paulo, 2013.

MARQUES, S. B. e DALLARI, S. G. Garantia do direito social à assistência farmacêutica no Estado de São Paulo. Revista de Saúde Pública, São Paulo, v. 41(1), p. 101-107, 2007.

MESSEDER, A. M.; OSORIO-DE-CASTRO, C. G. S.; LUIZA, V. L. Mandados judiciais como ferramenta para garantia do acesso a medicamentos no setor público: a experiência do Estado do Rio de Janeiro, Brasil. In: Cadernos de Saúde Pública, Rio de Janeiro, v. 21(2) , p. 525-534, 2005.

NOLTE, D.; SCHILling-VACAFLOR, A. (Org.). New Constitutionalism in Latin America: Promises and Practices. 1 ed. Farnham, Burlington: Ashgate Publishing, 2012.

O'DONELL, G. A. Delegative democracy. Journal of democracy, v. 5, n. 1, p. 55-69, 1994. 
OLIVEIRA, V. E. Judiciário e privatizações no Brasil: existe uma judicialização da política? Dados - Revista de Ciências Sociais, v. 48, n. 3, p. 559-587, 2005.

.; NORONHA, L. N. T. Judiciary-Executive relations in Policy Making: the case of drug distribution on the State of São Paulo. Brazilian Political Science Review, v. 5, n. 12, p. 10-38, 2011.

PEPE, V. L. E. et al. Caracterização de demandas judiciais de fornecimento de medicamentos "essenciais" no Estado do Rio de Janeiro, Brasil. Cadernos de Saúde Pública, Rio de Janeiro, v. 26. n. 3, p.461-471, 2010.

PEREIRA, J. R. et al. Análise das demandas judiciais para o fornecimento de medicamentos pela secretaria de Santa Catarina nos anos de 2003 e 2004. Ciência \& Saúde Coletiva, v. 15, supl. 3, p. 3551-3560, 2010.

PINHEIRO, A. C. Judiciário e Economia no Brasil. São Paulo: Editora Sumaré, 2000.

RIPLEY, R. B. Stages of the policy process. In: MCCOOL, D. C. Public policy theories, models, and concepts: an anthology. New Jersey: Prentice Hall, 1995.

SADEK, M. T. O Poder Judiciário na Reforma do Estado. In: SOLA, L. (Org.). Sociedade e Estado em Transformação. Brasília: ENAP; São Paulo: UNESP, 2001.

. Poder Judiciário: Perspectivas de Reforma. Opinião Pública (UNICAMP), Campinas, v. X, n.1, p. 01-62, 2004.

.; ARANTES, R. B. A crise do Judiciário e a visão dos juízes. Revista USP, São Paulo, v. 21, p. 34-45, 1994.

SANTIAGO, A. F. P. Judicialização de políticas sociais como estratégia do poder judiciário: o Fórum da Saúde e o Cadastro Nacional de Adoção. 2016. p. 357. 
Tese (Doutorado em Sociologia) - Centro de Filosofia e Ciências Humanas, Universidade Federal de Pernambuco, Pernambuco, 2016.

SANTOS, W. G. Cidadania e justiça. Rio de Janeiro: Campus, p. 11-14, 1979.

SCHEFFER, M.; SALAZAR, A. L.; GROU, K. B. O remédio via justiça: um estudo sobre o acesso a novos medicamentos e exames em HIV/Aids no Brasil por meio de ações judiciais. Série Legislação, n. 3, p. 24-38. 2005.

SCHEDLER, A. Conceptualizing accountability. In: SCHEDLER, A.; DIAMOND, L; PlatTNER, M. F. (Eds). The self-restraining state: Power and accountability in new democracies, Boulder and London: Lynne Rienner Publishers, 1999.

STONE SWEET, A. Governing with Judges. Constitutional Politics in Europe. Oxford University Press, 2000.

TATE, N.; VAllindER, T. The Global Expansion of Judicial Power. New York, New York University Press, 1995.

TEIXEIRA, S. M. F. Retomar o debate sobre a reforma sanitária para avançar o Sistema Único de Saúde (SUS). Revista de Administração de Empresas, v. 49, n. 4, p. 472-480, 2009.

TOMIO, F. R. L.; FILHO, R. I. N. Accountability e independência judiciais: uma análise da competência do Conselho Nacional de Justiça (CNJ). Revista de Sociologia e Politica, Curitiba, v. 21, n. 45, p. 29-46, Mar. 2013.

WANG, D. Courts as healthcare policy-makers: the problem, the responses to the problem and the problems in the responses. Research paper series - Legal Studies, Paper n. 75, 2013. Disponível em: <http://bibliotecadigital.fgv.br/dspace/handle/10438/11198>. Acesso em: 20 jul, 2016. 


\section{APÊNDICE A - Roteiro de Entrevista}

\section{Identificação do entrevistado}

- Nome; cargo. Provem da magistratura ou não? Tem alguma pós-graduação ou formação específica na área da saúde?

- Qual é o seu envolvimento com a judicialização da Saúde:

○ Gestor

- Formulador de ações/demandas

○ Julgador de ações

- Especialista na área

\section{Caracterização da judicialização da saúde}

- Quais fatores principais você elencaria como principais motivadores da judicialização da saúde?

- Quais fatores você diria que são dominantes nas decisões dos juízes?

- Você enxerga a judicialização da saúde como fenômeno majoritariamente positivo ou negativo? Quais são os saldos positivos e negativos do fenômeno?

\section{Impacto da Judicialização da Saúde}

- Quais seriam, na sua opinião, os principais impactos - positivos e negativos - da judicialização no orçamento e nas politicas públicas para a saúde?

- Como você caracterizaria a interação entre gestores públicos e membros do judiciário no que tange às questões de judicialização da saúde? (Existente; inexistente. De cooperação; conflituosa. Há diálogo ou não?)

\section{Fórum}

- Qual é a sua participação no Fórum (posição: representa que entidade; qual é o grau de envolvimento)?

- Como você veio a compor o Fórum? Como se dá a seleção dos membros?

- Como o Fórum está estruturado (nacional e regionalmente)? Existem sub-comissões?

- Qual é a rotina de trabalho do Fórum? Houve evolução ao longo do tempo?

- Na sua opinião, por qual motivo o Fórum foi instituído?

- Quais seriam os principais objetivos gerais do Fórum?

- Quais são os principais espaços de discussão e decisão ?

- Como você caracterizaria a interação entre gestores públicos e membros do judiciário nesses espaços?

- Você enxerga diferença no envolvimento e nos trabalhos que os diversos atores pertencentes ao Fórum desenvolvem?

- Você enxerga posicionamentos muito diferentes entre os participantes? Se sim, como são encaminhados os trabalhos nesses casos?

- Você considera que a maneira como o Fórum está organizado contribui para atingir os objetivos que você elencou? Como/Por que?

- Quais iniciativas do Fórum você considera mais importante, e quais impactos/resultados trouxeram? 


\section{APÊNDICE B - Entrevistas realizadas}

Realizaram-se algumas entrevistas, todas semi-estruturadas a partir de um roteiro previamente preparado, com espaço para questões exploratórias. A seleção de pessoas foi feita de modo a incluir representantes tanto do sistema de justiça (poder Judiciário, Ministério Público e Defensoria Pública), quanto representantes do sistema de saúde (Ministério da Saúde, CONASS e CONASEMS). Também foi selecionado um servidor do CNJ que acompanha as atividades do Fórum desde sua criação até o ano da conclusão do campo, 2016.

$\mathrm{O}$ anonimato foi oferecido a todos os entrevistados. Aqueles que abriram mão dessa garantia foram nominalmente citados ao longo do trabalho.

\begin{tabular}{|c|c|c|}
\hline Entrevistado & Perfil & $\begin{array}{l}\text { Numero de } \\
\text { Entrevistas }\end{array}$ \\
\hline Indivíduo 1 & $\begin{array}{l}\text { Supervisor do Fórum da Saúde, advindo da } \\
\text { magistratura. }\end{array}$ & 1 \\
\hline Indivíduo 2 & $\begin{array}{l}\text { Supervisor do Fórum da Saúde, advindo do } \\
\text { Ministério Público. }\end{array}$ & 1 \\
\hline Indivíduo 3 & $\begin{array}{l}\text { Membro do Comitê Nacional e de Comitê } \\
\text { Estadual, advindo da magistratura. }\end{array}$ & 1 \\
\hline Indivíduo 4 & $\begin{array}{l}\text { Membro do Comitê Nacional e de Comitê } \\
\text { Estadual, advindo da magistratura. }\end{array}$ & 1 \\
\hline Indivíduo 5 & $\begin{array}{l}\text { Membro de Comitê Estadual, advindo da } \\
\text { magistratura. }\end{array}$ & 1 \\
\hline Indivíduo 6 & $\begin{array}{l}\text { Membro do Comitê Nacional, representante do } \\
\text { CONASS. Advogada especialista em direito } \\
\text { sanitário e saúde pública. }\end{array}$ & 1 \\
\hline Indivíduo 7 & $\begin{array}{l}\text { Membro do Comitê Nacional, representante do } \\
\text { CONASEMS. Advogada especialista em direito } \\
\text { sanitário. }\end{array}$ & 1 \\
\hline Indivíduo 8 & $\begin{array}{l}\text { Membro do Comitê Nacional, representante do } \\
\text { CONASS. Médica especialista em Saúde } \\
\text { Pública. }\end{array}$ & 1 \\
\hline Indivíduo 9 & $\begin{array}{l}\text { Membro de Comitê Estadual, advindo da } \\
\text { Defensoria Pública. }\end{array}$ & 1 \\
\hline Indivíduo 10 & Servidor do CNJ. Bacharel em Direito & 1 \\
\hline
\end{tabular}

